521
12

$920 \mathrm{f}$ 

$\left.\begin{array}{l}\text { 66th Congress, } \\ \text { 2d Session. }\end{array}\right\}$ HOUSE OF REPRESENTATIVES. $\left\{\begin{array}{l}\text { Report } \\ \text { No. } 596 .\end{array}\right.$

\section{S 21}

\section{.22}

$1920 \mathrm{~b}$

GRICULTURE APPROPRIATION BILL.

Copy 1

smakuak o, wa20.-Committed to the Committee of the Whole House on the state of the Union and ordered to be printed.

S. Conoress, it ouse,

Mr. Haugen, from the Committee on Agriculture, submitted the following

\section{REPORT.}

[To accompany H. R. 12272.]

The Committee on Agriculture submits the following report to accompany bill (H. R. 12272) making appropriations for the Department of Agriculture for the fiscal year ending June 30, 1921.

The committee held hearings extending over a period of six weeks on the estimates presented by the department. Representatives of the Department of Agriculture and others interested appeared before the committee and discussed in detail the various items.

The total sum carried by the present bill is $\$ 30,540,034$. This is a decrease of $\$ 3,359,727$ below the appropriation act for the fiscal year 1920 , a decrease of $\$ 7,132,823$ below the regular and supplemental estimates submitted by the department, and a decrease of $\$ 11,558,204$ below the estimates of the bureaus. The committee has not been unmindful of the valuable work of the Department of Agriculture and the need for supporting and enlarging many important activities for the benefit of the farmers, but, in view of the unusual financial conditions confronting the country at the present time, the committee believes it imperative to economize in every possible way and has endeavored to accomplish this result in the present bill without seriously crippling the work of the department. While the decreases are large, they have been made principally in regulatory and administrative items rather than in items providing for food-production activities. Increases have been provided in a number of the items, but in each case only after a very thorough investigation of the necessity therefor, and these increases are recommended by the committee.

The following table shows the appropriations for the present fiscal year, the estimates submitted by the various bureaus and offices to the Secretary of Agriculture, the regular and supplemental estimates submitted by the Department of Agriculture to the committee, the amount carried in this bill, the increases and decreases of the bill as compared with the estimates submitted by the department, and the increases and decreases of the bill as compared with the appropriation for the present fiscal year. 
Estimate of appropriations, 1921, United States Department of Agriculture.

\begin{tabular}{|c|c|c|c|c|c|c|}
\hline Bureau or office. & $\begin{array}{l}\text { A ppropri- } \\
\text { ation in } \\
\text { Agricul- } \\
\text { tural act, } \\
1920 .\end{array}$ & $\begin{array}{c}\text { Bureau } \\
\text { or office } \\
\text { estimates, } \\
1921 .\end{array}$ & $\begin{array}{l}\text { Depart- } \\
\text { ment } \\
\text { estimates, } \\
1921 .\end{array}$ & $\begin{array}{l}\text { Reported } \\
\text { by House } \\
\text { commit- } \\
\text { tee. }\end{array}$ & $\begin{array}{c}\text { Increase } \\
\text { over }(+) \\
\text { or decrease } \\
\text { below }(-) \\
\text { department } \\
\text { estimates, } \\
1921 .\end{array}$ & $\begin{array}{l}\text { Increase } \\
\text { over }(+) \\
\text { or decrease } \\
\text { below (-) } \\
1920 \\
\text { appropri- } \\
\text { ations. }\end{array}$ \\
\hline fif & $\$ 500,520$ & $\$ 477,140$ & $\$ 475,860$ & $\$ 466,940$ & $\$ 8,920$ & \\
\hline & & & 611,990 & & $-\quad 289,860$ & \\
\hline & $1,880,210$ & $2,4 f$ & $2,228,150$ & 1,8 & & $-\quad 1,2$ \\
\hline & $5,783,231$ & 6,92 & $6,118,451$ & 5,327 , & - 791, & $\begin{array}{l}-\quad 455,9 \\
-\quad 340,9\end{array}$ \\
\hline Bureau of Plar & $3,379,638$ & $\begin{array}{r}3,920,098 \\
97,063,427\end{array}$ & $\begin{array}{l}3,606,898 \\
6,557,895\end{array}$ & $3,038,639$ & - $\quad 568,259$ & - 340,99 \\
\hline Forest Service.... & $5,966,869$ & $\left\{\begin{array}{r}1 \\
139,755\end{array}\right.$ & $\begin{array}{l}0,051,795 \\
1 / 39,755\end{array}$ & \}$^{5,777,842}$ & - 819,808 & $-189,027$ \\
\hline $\begin{array}{l}\text { Bureau of Chemist } \\
\text { Bureau of Soils.... }\end{array}$ & $\begin{array}{r}1,391,571 \\
491,235\end{array}$ & $1,502,411$ & $\begin{array}{r}1,424,511 \\
620,095\end{array}$ & $1,321,591$ & $\begin{array}{r}102,920 \\
-\quad 79,060\end{array}$ & $\begin{array}{l}-69,980 \\
+\quad 49,800\end{array}$ \\
\hline Bureau of Entomology . & $1,371,360$ & $\left\{\begin{array}{r}2,163,940 \\
2105,000\end{array}\right.$ & $\begin{array}{r}1,219,260 \\
2105,000\end{array}$ & $\{1,073,480$ & $-\quad 250,780$ & $-\quad 297,88_{0}$ \\
\hline $\begin{array}{l}\text { Bureau of Bio } \\
\text { Division of Ac }\end{array}$ & 742,170 & $1,282,655$ & 978,005 & 782,170 & $-195,835$ & 40,000 \\
\hline & $\begin{array}{r}44,620 \\
240\end{array}$ & $\begin{array}{r}50,620 \\
379,030\end{array}$ & $\begin{array}{r}50,620 \\
362,480\end{array}$ & $\begin{array}{r}48,220 \\
372\end{array}$ & $\begin{array}{r}2,400 \\
-\end{array}$ & \\
\hline Bur & 371,102 & $1,164,715$ & & $\begin{array}{l}372,570 \\
322,856\end{array}$ & $\begin{array}{l}+\quad 10 \\
-\quad 644\end{array}$ & $\begin{array}{l}+\quad 132,430 \\
-\quad 48,246\end{array}$ \\
\hline Libr: & & & & & $-\quad 10$ & + \\
\hline $\begin{array}{l}\text { Miscellaneous expe } \\
\text { ment of Agricultu }\end{array}$ & & & & & 5,000 & - \\
\hline e & & & & & + & \\
\hline & & 4,97 & 4,96 & 4,8 & $-\quad 102$ & $-\quad 39,700$ \\
\hline & & & & & -25 & $-\quad 103,70$ \\
\hline & & 3,45 & & & -54 & $-\quad 332,79$ \\
\hline & & & & & & 8,590 \\
\hline Federal Hor & & & & & - $\quad 67$, & $+\quad 40,050$ \\
\hline MISCELLANEOUS APPRO & & & & & & \\
\hline $\begin{array}{l}\text { Demonstrations on rec } \\
\text { projects................ }\end{array}$ & \multirow[t]{2}{*}{48,600} & & & & $-\quad 17$ & 18,600 \\
\hline $\begin{array}{l}\text { Ighting and preventing fo } \\
\text { ooperative fire protection }\end{array}$ & & $1,000,000$ & 1,00 & 250 & $-750,000$ & $+250,000$ \\
\hline $\begin{array}{l}\text { Cooperative fire protection } \\
\text { ested watersheds of } \mathrm{n} \\
\text { streams........................... }\end{array}$ & \multirow[t]{2}{*}{100,000} & \multirow[t]{2}{*}{500,000} & \multirow[t]{2}{*}{200,000} & 75,000 & \multirow[t]{2}{*}{$-125,000$} & $-\quad 25,000$ \\
\hline $\begin{array}{l}\text { Experiments and demonstrations } \\
\text { in live-stock production in the } \\
\text { cane-sugar and cotton districts } \\
\text { of the United States............... }\end{array}$ & & & & & & \multirow{2}{*}{$-\quad 13,500$} \\
\hline $\begin{array}{l}\text { Experiments in dairying and live- } \\
\text { stock production in semiarid and } \\
\text { irrigated districts of the western } \\
\text { United States....................................... }\end{array}$ & 60,000 & 60,000 & 60,000 & 46,500 & $-\quad 13,500$ & \\
\hline $\begin{array}{l}\text { United States.... } \\
\text { Eradication of the } \mathrm{fo}\end{array}$ & 40,000 & 40,000 & 40,000 & 30,000 & $-\quad 10,000$ & $-\quad 10,000$ \\
\hline $\begin{array}{l}\text { and other co } \\
\text { animals.... }\end{array}$ & & & 0 & & 00 & \\
\hline $\begin{array}{l}\text { Eradi } \\
\text { Acqui }\end{array}$ & 800 & 573,300 & 388,560 & 288,560 & $-\quad 100,000$ & - 307,2 \\
\hline & 600 & & & & & \\
\hline & & 155,000 & 100,000 & 25,000 & $-75,000$ & + \\
\hline Agricultur & 100,000 & & & & 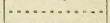 & $-100,000$ \\
\hline $\begin{array}{l}\text { Grand total, Depa } \\
\text { Agriculture..... }\end{array}$ & 899,761 & $42,098,238$ & $37,672,857$ & $30,540,034$ & $-7,132,823$ & $-3,3$ \\
\hline
\end{tabular}

1 Supplemental estimate for administration of the Thunder Mountain area, Idaho.

2 Supplemental estimate for control of the Japanese beetle.

\section{REVENUES AND RECEIPTS.}

In considering the above table it should be borne in mind that the annual, permanent, and emergency appropriations of the Department of Agriculture are offset to some extent by certain revenues and receipts resulting from or incident to its activities. These revenues and receipts during the fiscal year 1919 amounted to $\$ 15,607,150.98$, and were covered into the Treasury. They include the following items:

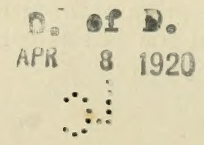


Receipts from national forests, $\$ 4,358,414.86$. - The receipts from the national forests were derived from the following sources, and represent an increase of $\$ 783,484.79$ over the year 1918:

(a) Timber, $\$ 1,526,188$ : Sales of all classes of stumpage on the national forests, payments for timber destroyed on rights of way or other uses, payments for timber cut or removed without previous permit, and damages assessed against persons setting fire to forest areas.

(b) Grazing, \$2,609,169.85: Payments for grazing privileges on national forest ranges for cattle, horses, swine, sheep, and goats, and for unauthorized use of grazing areas.

(c) Special uses, \$223,057.01: Payments for use of forest lands for various purposes, such as residences, camps, cabins, hotels, rights of way, agriculture, wharves, water power, telegraph and telephone lines, reservoirs, conduits, etc., and use of forest areas for turpentine extraction.

Benefits derived by States from receipts from national forests. - Under existing law 10 per cent of the forest receipts is expended by the Secretary of Agriculture in the construction of roads and trails, and 25 per cent of the forest receipts is paid to the States by the Federal Government for the benefit of county schools and roads. The amounts expended in or paid in each State during the fiscal year. 1919 are shown below:

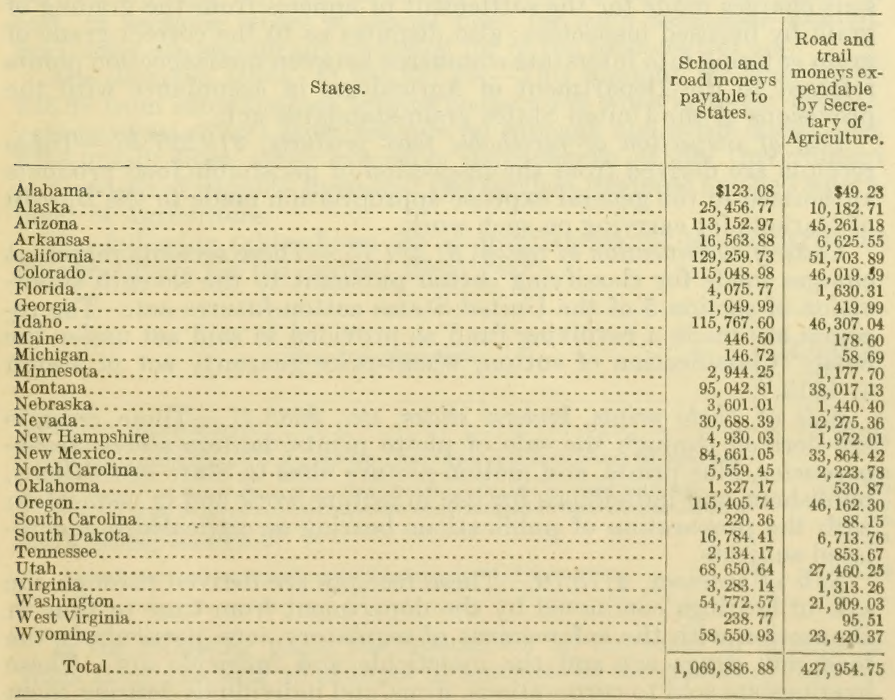

Additional benefits derived by Arizona and New Mexico from receipts from national forests.- The States of Arizona and New Mexico received additional shares of national-forest receipts for their school funds on account of school lands included within national forests, as follows: Arizona, \$58,775.83; New Mexico, \$20,091.49. 
Telegrams over Government lines, \$6,146.75.-These receipts are derived through the transmission of private messages over Weather Bureau telegraph lines in isolated regions where commercial lines are not yet available.

Sale of cotton standards, \$5,665.31.--These receipts are derived through the sale of practical forms of the official cotton standards prepared by the department to the various exchanges, spot-market dealers, merchants, cotton mills, agricultural colleges, and textile schools.

Cost of cotton-futures disputes, \$10,45\%.20.-These receipts are derived through the settlement of disputes referred to the department from time to time by either party to a contract of sale of cotton for future delivery, for determination as to the quality, grade, or length of staple of the cotton, in accordance with the provisions of the United States cotton-futures act.

Sale of loose cotton, \$34,693.24.-. In the preparation of practical forms of the official cotton standards it is necessary for the department to purchase in the open market considerable quantities of cotton in order to match the various types and classes of cotton. A large quantity of the cotton thus purchased is found unsuitable for use in making copies of the official cotton standards, and this is disposed of to dealers at the best price obtainable.

Cost of grain-standards appeals, $\$ 7,545.91$. - These receipts represent charges made for the settlement of appeals from the grading of grain by licensed inspectors; also disputes as to the correct grade of grain entering in to interstate commerce between noninspection points referred to the Department of Agriculture in accordance with the provisions of the United States grain-standards act.

Cost of inspection of perishable food products, \$19,227.56.-These receipts are derived from the inspection of perishable food products authorized in the general expense appropriation made to the Bureau of Markets for carrying on such work.

Costs of classification of cotton, $\$ 1,491.75$. - These receipts represent charges made for classifying cotton pursuant to the seventh subdivision of section 5 of the United States cotton-futures act. The receipts are made a revolving fund as provided in said act under the head "Classification of cotton, wheat-price guaranty act of March 4, 1919."

Sale of photo prints, lantern stides, etc., \$688.4\%.-These receipts are derived through the sale of photo prints, lantern slides, transparencies, blue prints, and motion-picture films to State institutions, publishers, and individuals for use in lecture work and in connection with the preparation of publications bearing on agriculture and related subjects.

Sale of hearings, $\$ 178.70$. - These receipts are derived through the sale of hearings conducted by the department from time to time in connection with the enforcement of regulatory acts, particularly the food and drugs act and the insecticide and fungicide act. These hearings are sold to corporations, firms, and individuals desiring them at the rate of 10 cents per folio to eover the cost of preparing them.

Sale of card indexes, \$202.75.-These receipts are derived through the sale of card indexes of experiment station literature to various agricultural colleges, experiment stations, educational institutions, and libraries throughout the country. 
Sale of other miscellaneous property and collections, \$244,606.16.This covers the sale of unserviceable property owned by the department which has been passed upon and condemned by a board of survey appointed by the Secretary of Agriculture. It also covers the proceeds derived through the sale of farm products obtained at the various experiment stations of the department, other than the insular experiment stations; animals and animal products no longer needed in the work of the department; forest maps and maps and publications of the Weather Bureau; pathological and zoological specimens; samples of pure sugars and naval stores; microscopical specimens, etc.

Sale of products, agricultural stations, Alaska, Hawaii, Porto Rico, Guam, and the Virgin Islands, \$4,284.40.-These receipts are derived through the sale of agricultural products obtained on the land belonging to the agricultural experiment stations in Alaska, Hawaii, Porto Rico, island of Guam, and the Virgin Islands.

Sale of seeds to farmers, $\$ 859,650.48$. - These receipts are derived through the sale of seeds to farmers for cash, at cost, in sections where, on account of drought or other unfavorable conditions, such assistance was needed. Such sales are specifically provided for in the food-production act.

Sale of nitrate of soda to farmers, $\$ 8,768,268.85$. - These receipts are derived through the sale of nitrate of soda to farmers for cash, at cost, in sections where a special need for such assistance existed. Such sales are specifically provided for in the food-control act.

Miscellaneous items, \$1,285,631.59.-This amount includes \$547,928.89 from contributions toward cooperative work in forest investigations; $\$ 441,678.21$ from refunds on mileage and scrip books, and $\$ 296,024.49$ from other executive departments of the Government in payment of supplies furnished and services rendered by the Department of Agriculture.

The following table shows the appropriations for the Department of Agriculture for the current fiscal year:

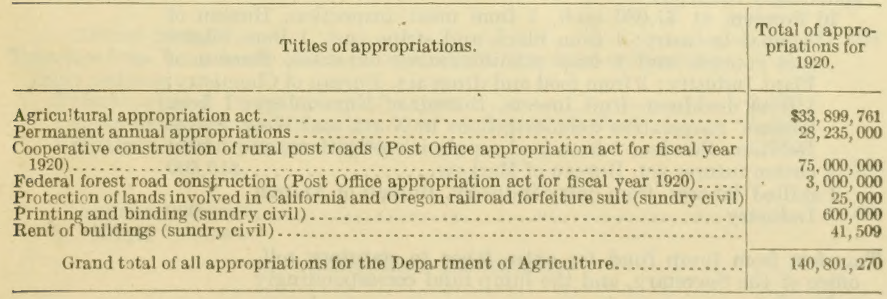

In the following pages the reasons for all increases in appropriations are given, and all changes in amounts in the statutory rolls are indicated. 


\section{OFFICE OF THE SECRETARY.}

\section{STATUTORY SALARIES.}

(P. 2, line 3.)

The statutory roll of the office of the Secretary carries a decrease of $\$ 33,580$, as indicated in detail in the following table:

Places dropped:

1 assistant secretary . . . . . . . . . . . . . . . . . . . . . $\$ 5,000$

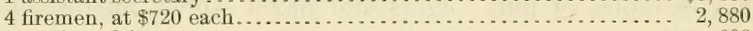

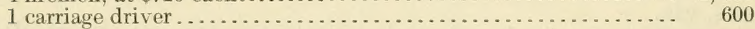

Transfers to statutory roll. Division of Publications; and the Secretary's roll correspondingly reduced:

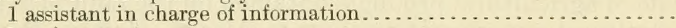

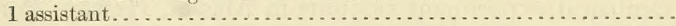

1 assistant editor . . . . . . . . . . . . . . . . . . . . . . . . .

4 assistant editors, at $\$ 1,800$ each. . . . . . . . . . . . . . . . . .

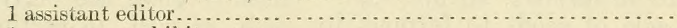

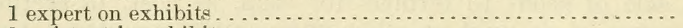

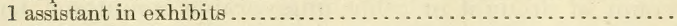

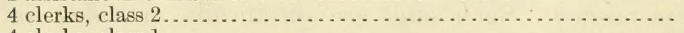

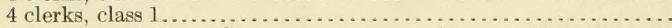

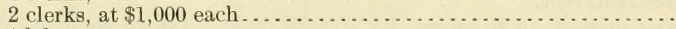

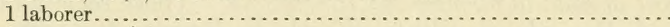

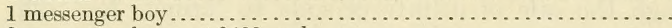

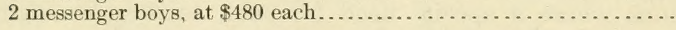

Transfers from extra labor fund, office of the Secretary, and that fund correspondingly reduced:

2 charwomen, at $\$ 240$ each, 1 to statutory roll, Division of Publications, and 1 to statutory roll, Bureau of Crop Estimates......

Reduction in "extra labor" fund on account of transfers to statutory roll, office of the Secretary ..........................

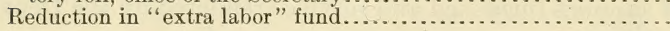

Transfers from funds of other bureaus, which funds have been correspondingly reduced:

10 firemen, at $\$ 1,080$ each, 1 from meat inspection, Bureau of Animal Industry; 1 from black and stripe rust, 1 from blister rust control, and 1 from administrative expenses, Bureau of Plant Industry; 2 from food and drugs act, Bureau of Chemistry; 1 from deciduous fruit insects, Bureau of Entomology; 1 from farmers' cooperative demonstrations in North and West, States Relations Service; 1 from food supply investigations, and 1 from cotton futures act, Bureau of Markets................ $\$ 10,800$ 1 skilled laborer, from dairy industry, Bureau of Animal
Industry ....................................

Transfers from lump fund for extra labor to statutory roll, office of the Secretary, and the lump fund correspondingly reduced:

1 superintendent of telegraph and telephones..............

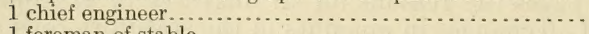

1 foreman of stable ....................................

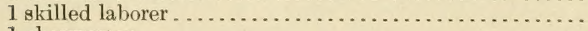

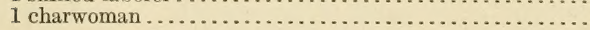

6,080

Actual decrease............................ $\overline{33,580}$ 


\section{OFFICE OF FARM MANAGEMENT.}

STATUTORY SALARIES.

(P. 4, line 17.)

The statutory roll of the Office of Farm Management carries a decrease of $\$ 12,300$, as indicated in the following table:

Places dropped:

9 clerks, at $\$ 900$ each.................................... $\$ 8,100$

5 clerks or map tracers, at $\$ 840$ each.......................... 4,200

Actual decrease ................................ 12,300

GENERAL EXPENSES.

Farm management and farm practice investigations (p. 5, line 6).There is an increase in this item of $\$ 31,840$. This amount has been added to the sum set aside in the proviso for ascertaining the cost of production of the principal staple agricultural products, as has $\$ 23,160$, which is deducted from the amount heretofore available for general farm-management work, the committee being of the opinion that a large appropriation should be devoted to this important investigation.

\section{WEATHER BUREAU.}

STATUTORY SALARIES.

(P. 5, line 18.)

The statutory roll of the Weather Bureau carries an apparent increase of $\$ 4,020$, but there is an actual decrease of $\$ 1,200$, as indicated in detail in the following table:

Places dropped:

4 firemen, at $\$ 720$ each ............................... $\$ 2,880$

New places:

2 firemen, at $\$ 840$ each................................. 1,680

Actual decrease .................................. $\$ 1,200$

Transfers from lump funds of this bureau, which have been correspond-

ingly reduced:

2 clerks, class 1 , from aerological stations.................... 2,400

1 supervising instrument maker, from aerological stations.......... 1,620

1 repairman, from station salaries...................... 1,200

Apparent increase ................................ $\frac{5,220}{4,020}$

GENERAL EXPENSES.

Expenses outside of Washington (p. 9, line 10).-There is an apparent decrease in this item of $\$ 1,200$, but, as that amount has been transferred to the statutory roll, there is actually no change.

Aerological investigations (p. 9, line 18).-There is an apparent decrease in this item of $\$ 4,020$, but, as that amount has been transferred to the statutory roll, there is actually no change. 


\title{
BUREAU OF ANIMAL INDUSTRY.
}

\author{
STATUTORY SALARIES.
}

(P. 10, line 2.)

The statutory roll of the Bureau of Animal Industry carries an apparent increase of $\$ 103,240$, but there is no actual increase, as indicated in detail in the following table:

Transfers from lump funds of this bureau, which funds have been correspondingly reduced:

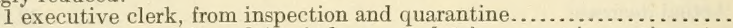

3 clerks, class 4,2 from dairy industry, and 1 from meat inspection.....

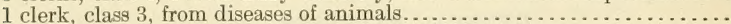

4 clerks, at $\$ 1,500$ each, 1 from inspection and quarantine, 1 from dairy industry, 1 from eradicating hog cholera, and 1 from meat inspection.

2 clerks, class 2,1 from eradicating hog cholera and 1 from meat inspec-

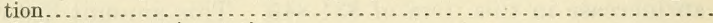

1 clerk, from meat inspection . . . . . . . . . . . . . . . . . . . . .

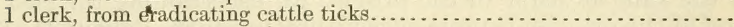

1 clerk, from meat inspection. . . . . . . . . . . . . . . . . . . . . . . .

39 clerk, class 1,1 from inspection and quarantine, 8 from tuberculosis eradication, 5 from eradicating cattle ticks, 2 from dairy industry, 2 from eradicating hog cholera, and 21 from meat inspection..........

11 clerks, at $\$ 1.100$ each. 1 from inspection and quarantine, 1 from eradicating cattle ticks, 1 from tuberculosis eradication, 4 from animal husbandry, 3 from eradicating hog cholera, and 1 from meat in-

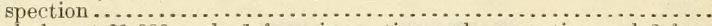

4 clerks, at $\$ 1,080$ each, 1 from inspection and quarantine and 3 from

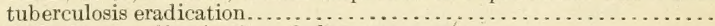

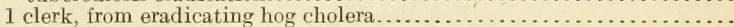

7 clerks, at $\$ 1,000$ each, 3 from tulerculosis eradication, 2 from dairy in-

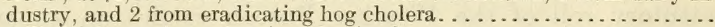

1 skilled laborer, from abortion of animals. . . . . . . . . . . . . . . . .

1 skilled laborer, from tuberculosis eradication. . . . . . . . . . . . . . . .

1 skilled laborer, from dairy industry . . . . . . . . . . . . . . . . . . . . . . .

2 messengers or laborers, at $\$ 840$ each, 1 from dairy industry and 1 from

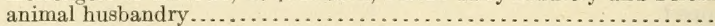

1 messenger boy, from tuberculosis eradication..................

9 messenger boys, at $\$ 480$ each, 1 from inspection and quarantine, 2 from tuberculosis eradication, 1 from dairy industry, 1 from animal husbandry, 1 from diseases of animals, 1 from abortion of animals, 1 from eradicating hog cholera, and 1 from meat inspection.............

1 charwoman, from meat inspection . . . . . . . . . . . . . . . . . . .

$\$ 2,000$

5,400

1,600

6,000

2,800

1,380

1,320

1,260

46,800

12,100

4,320

1,020

7,000

1,200

1,000

900

1,680

660

4,320

Apparent increase

103,240

\section{GENERAL EXPENSES}

Inspection and quarantine (p. 13, line 3).-There is an apparent decrease in this item of $\$ 5,360$, but, as $\$ 7,360$ has been transferred to the statutory roll, the actual increase is $\$ 2,000$. This amount will be used for the inspection and testing of animals for export. This work is constantly inereasing. In recent months there has been an unusual demand for the bureau inspectors to test animals for export and to inspect the vessels carrying such animals.

Tuberculosis of animals (p. 13, line 13).- There is an apparent decrease in this item of $\$ 200,000$, but, as $\$ 19,560$ has been transferred to the statutory roll, the actual decrease is $\$ 180,440$. The decrease is due to a reduction of $\$ 500,000$ in the in lemnity fund. The experience of the past year has shown that less money will be required 
for intemnities and a larger amount for alministrative and operating expenses. The committee therefore increased the amount for administrative and operating expenses from $\$ 500,000$ to 8800,000 , $\$ 100,000$ of which it recommends be marle immediately arailable: and decreased the amount for indemnities from $\$ 1,000,000$ to $\$ 50(0,000$.

The word "hereafter" has been adcled to the thired proviso, on page 15 , relative to the interstate shipment of cattle for immediate slaughter; this will make the legislation permancent and obviate the neeessity of repeating the language ammally in the appropriation bill.

Tick eradication (p. 16, line 3).-There is an apparent decrease in this item of $\$ 60,820$, but, as $\$ 8,420$ has be'm transferred to the statutory roll, the actual decrease is $\$ 52,4() 0$. 'This amount has heret of ore been used for live-stock and dairy demonstration work, in cooperation with the States Relations service, but the committee recommends that this work be discontinued. The language pertaining to this work has therefore been omitted. The proviso has also been amended so as to prohibit the purchase of animals, as well as materials, in connection with tick-eradication demonstrations.

Dairy investigations (p. 16, line 13).--There is an apparent decrease in this item of $\$ 50,370$, but as $\$ 11,720$ has been transferred to the statutory roll of the bureau, and $\$ 900$ to the statutory roll of the Secretary's Office, the actual decrease is $\$ 37,750$.

Animal husbandry incestigations (p. 16, line 17). - There is an apparent decrease in this item of $\$ 58,50(0)$, but as $\$ 5,720$ has been transferred to the statutory roll, the actual decrease is $\$ 52,7 \$ 0, \$ 16,940$ in the amount set aside for experiments in breeding and maintenance of horses for military horses, $\$ 33,640$ in the amount set aside for poultry feeding and breeding, and $\$ 2,200$ in the amount for general animal husbandry work.

Animal disecese investigations (p. 17, line 11).- There is an apparent decrease in this item of $\$ 1 \$, 160$, but as $\$ 3,760$ has been transferred to the statutory roll, the actual decrease is $\$ 14,400$.

Inasmuch as the amount set aside in the proriso for the investigntion of contagious abortion has been redueed $\$ 24,400$, howerer, there is thereby released for other work the sum of $\$ 10,000$, which the committee recommends be used for the investigation of roundworm of hogs. These parasites are responsible for losses among young pigs amounting to millions of dollars each year.

Ilog cholera (p. 17, line 21).-There is an apparent decrease in this item of $\$ 131,045$, but, as $\$ 12,100$ has been transferred to the statutory roll, there is an actual decrease of $\$ 118,945$.

Dourine eradication (p. 18, line 11).-There is a decrease in this item of $\$ 23,600$.

\section{MEAT INSPECTION.}

\section{(P. 18, line 19.)}

There is an apparent decrease in this item of $\$ 11,3 \$ 0$, but, as $\$ 35,680$ has been transferred to statutory rolls, there is an actual increase of $\$ 24,300$ to be used for salaries.

The language of the paragraph has been amended by inserting the words "including the purchase of tags, stamps, and labels printed in course of manufacture." The languace of recent enactments relatiro to printing, strictly construed, prevents the department from securing 
such supplies from any other source than the Government Printing Office, except with the previous consent of the Joint Committees on Printing. Attention is invited to the fact that similar authority has been carried in the legislative, executive, and judicial appropriation acts for a number of years, covering like supplies for the Treasury Department, this item reading: "For stationery, including tags, labels, and index cards printed in course of manufacture." These articles are used for the marking of coins and other articles-uses which appear to be exactly comparable with those to which the meatinspection supplies are devoted.

The provisions regarding the inspection of equine meat and for the payment of overtime work in packing establishments have been omitted, being permanent legislation, but proper reference has been made thereto by the addition of the following words: "as extended to equine meat by the act of July 24,1919 (public No. 22, 66th Cong.)."

\section{BUREAU OF PLANT INDUSTRY.}

\section{STATUTORY SALARIES.}

(P. 19, line 5.)

The statutory roll of the Bureau of Plant Industry carries an apparent increase of $\$ 35,680$, but there is an actual decrease of $\$ 1,200$, as indicated in detail in the following table:

Transfers from lump funds of this bureau, which funds have been correspondingly reduced:

1 executive clerk, from administrative expenses............ $\$ 1,980$

3 clerks, class 4,1 from blister-rust control, 1 from black and stripe rust investigations, and 1 from purchase and distribution of valuable seeds...................................

3 clerks, class 3,1 from citrus canker eradication, 1 from crop physiology, 1 from barberry eradication (and 1 from demon-

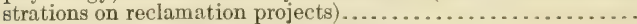

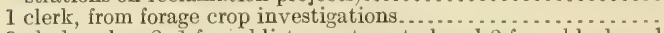

3 clerks, class 2 , 1 from blister-rust control and 2 from black and

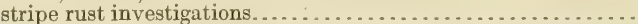

12 clerks, class 1,1 from forest pathology, 1 from blister-rust control, 2 from cotton and truck diseases, 1 from cereal investigations, 2 from black and stripe rust investigations, 1 from barberry eradication, 1 from alkali and drought resistant plants, 1 from western irrigation agriculture, 1 from new and rare seeds,

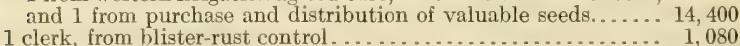

1 messenger or laborer, from black and stripe rust investigations. $\quad 720$

1 general mechanic, from Arlington Farm................ 1, 400

1 mechanical assistant, from horticultural investigations........ 1,400

Place dropped:

1 blacksmith ................................... 1,200

Actual decrease.................................... 1,200

Apparent increase.................................. 35,680

GENERAL EXPENSES.

Citrus cunker (p. 21, line 21).-There is an apparent decrease in this item of $\$ 86,600$, but, as $\$ 1,600$ has been transferred to the statutory roll, the actual decrease is $\$ 85,000$.

Forest pathology (p. 22, line 14).-There is an apparent decrease in this item of $\$ 1,200$, but, as that amount has been transferred to the statutory roll, there is actually no change. 
White-pine b7ister must (p. 22, line 14).-There is an apparent decrease in this item of $\$ 6,560$, but as this amount has been transferred to statutory rolls, there is actually no change.

Cotton, truck, and forage crop investigations (p. 23, line 11).-There is an apparent increase in this item of $\$ 7,600$, but, as $\$ 2,400$ has been transferred to the statutory roll, the actual increase is $\$ 10,000$. This amount will be used for investigating a number of serious potate diseases, including a study of the potato wart in cooperation with the Federal Horticultural Board. There is a decrease of $\$ 14,700$ in the appropriation for the eradication of the potato wart under the Federal Horticultural Bourd. A group of potato diseases classed as "mosaic" also presents a series of difficult problems, including a determination of the exact nature of the eause of the diseases and of questions relating to their transmission by insects. The importance of this work is indicated by the fact that losses in infected fields frequently exceed 20 per cent.

C'rop physiology (p. 23, line 13).-There is an apparent deerease in this item of $\$ \$, 400$, but, as $\$ 1,600$ has been transferred to the statutory roll, the actual decrease is $\$ 6,800$.

Soil-fertitity investigations (p. 23 , line 2.2). - There is an increase of $\$ 10,000 \mathrm{in}$ this item. This amount will be used in mecting the increasing demands for information regarding new fertilizer materials During the past few years heary losses have resulted to farmers through the application of fertilizers regarding which no experience from their use was arailable. Many of these fertilizer materials were of comparatively little value and some were actually injurious. New nitrogen products will undoubtedle appear in fertilizers during the next few years, and these should he inrestiented promptly. It is proposed to investirate and give field tests to all materials representing new sources of potash, phosphoric acid, and nitrogen as they appear in the fertilizer market from time to time.

Crop acclimatization and fiber-plant investeations (p). 24, line 1). There is a decrease in this item of $81 \mathrm{~s},() 0()$. The provicion sotting

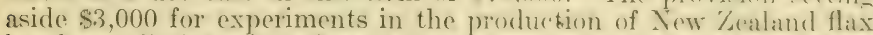
has been eliminated, as has also the proviso increasing the limit on the cost of farm buildings under this item.

Irug-plant and poisomons-plant imastigations. (p. 24, line !)1.-An increase of $\$ 1,000$ has been provided in this item for the extension of the investigations of stock-poisoning plants, in cooperation with the Bureau of Animal Industry.

Cereal investigations (p. 25, line 4).-There is an apparent decrease

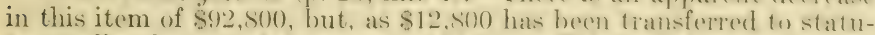
tory rolls, the actual decrease is $\$ S(0,000)$. This includes a reduetion of $\$ 50,000$ in the proviso for the investigation and eontrol of hlack rust, leaf rust, and stripe rust.

The provisos setting aside $840,0(0)$ for the study of (eorn impurevement and methods of corn production and 525 ,outi) for the investigations of corn root and stalli discises have been eliminated. This is done in order to simplify the languace of the paragraple, and alse (o) reduce the amount of cherieal and overhead expenses. Wut it is the committee's intention that the work heretefore carred on under these provisions should be continued.

Alkati and drought resistant plant imestigutions (p. 26. line :31.There is an apparent decrease in this item of $\$ 4.20()$, but, as $\$ 1.200$ 
has been transferred to the statutory roll, the actual decrease is $\$ 3,000$.

Sugar-plant investigations (p. 26, line 5).--There is a decrease in this item of $\$ 9,115$.

The provisos setting aside $\$ 10,000$ for the development and improv ment of American strain of sugar-beet seed and for investigations connection with the production of cane and sorghum sirups ha been eliminated. This merely eliminates superfluous language in $t$ ] item, but it is the thought of the committee that the work should carried on along present lines.

Dry-land agriculture investigations (p. 26, line 13).- There is decrease in this item of $\$ 9,000$.

Western irrigation agriculture investigations (p. 26, line 24).-Th. is an apparent decrease in this item of $\$ 21,200$, but, as $\$ 1,200$ ] been transferred to the statutory roll, there is an actual decrease $\$ 20,000$.

Pomological investigations (p. 27, line 9).--There is an increase this item of $\$ 27,000$. This amount will be used for the purchase land for two stations in California for the conduct of viticultr work. A proviso authorizing this purchase has been added. proviso in the present act setting aside $\$ 20,000$ for investiga and developing new grape industries has been eliminated.

Iorticultural investigations (p. 28, line 6).-There is an appa it decrease in this item of $\$ 1,400$, but, as this amount has been tr sferred to the statutory roll, there is actually no change. The ( nmittee recommends that $\$ 5,000$ of this appropriation be used for ae development of pure and desirable strains of sweet corn for a nmercial canning.

Nursery investigations (p. 28, line 13).-This is a new item. he necessity of restricting under the plant-quarantine act the importation of much of the nursery stock and other closely allied plant material hitherto brought into the United States in large quantities, in order to give adequate protection to horticultural and pomological interests against the introduction of dangerous insect pests and fungous diseases, together with the serious reduction during the past year or two in the usual supplies of stocks obtained under normal conditions from France and elsewhere, has served to emphasize the importance of dereloping domestic supplies of these materials.

Arlington farm (p. 28, line 19). - There is an apparent decrease in this item of $\$ 1,400$, but as that amount has been transferred to the statutory roll, there is actually no change.

Foreign seed and plant introduction (p. 29, line 1).-There is a decrease in this item of $\$ 50,000$. Inasmuch as the appropriation for the current fiscal year, however, includes $\$ 50,000$ for the pur hase of land, erection of buildings, ete., in connection with the establishment of a plant inspection and detention station, which amount is omitted in this bill there is actually no change in the funds available for" ('onducting the work under this item.

New and rare seed, forage-crop investigations (p. 29, line 8).-There is an apparent decrease in this item of $\$ 9,780$, but as $\$ 2,700$ has been transferred to the statutory roll, the actual decrease is $\$ 7,080$.

Administrative expenses (p. 29, line 17).-There is an apparent do(rease in this item of $\$ 3,060$, but, as $\$ 1,080$ has been transferred to the statutory roll of the Secretary's office, the actual decrease is $\$ 1,980$. 


\section{PURCHASE AND DISTRIBUTION OF VALUABLE SEEDS.}

\section{(P. 29, line 24.)}

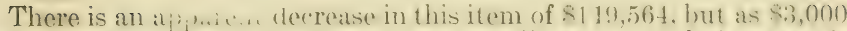
is been transferred to the statutory roll, the atual dereatse is 16,564 .

\section{FOREST SERVICE.}

STATUTORY SALARIES,

(P. 32, line 16.)

The statutory roll of the Forest ferrice curries an artual increase $\$ 2,520$, as indicated in detail in the following table:

v places:

1 forest supervisor

$\$ 3,240$

1 forest supervisor

2,880

8 forest supervisors, at $\$ 2,500$ each................. 20. 2000

16 forest supervisors, at $\$ 2,380$ each.................. . 38,080

14 forest supervisors, at $\$ 2,180$ each..................... $95,9: 20$

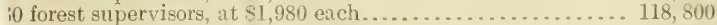

5 forest supervisors, at $\$ 1,780$ each.................. 8,900

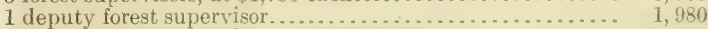

4 deputy forest supervisors, at $\$ 1,880$ each............ 7,520

5 deputy forest supervisors, at $\$ 1,780$ each............. 44,500

3 deputy forest supervisors, at $\$ 1,680$ each . . . . . . . . . . 47,040

j deputy forest supervisors, at $\$ 1,580$ each............ 23, 700

1 forest rangers, at $\$ 1,620$ exch . . . . . . . . . . . . . . . . . 17, 820

if forest rangers, at $\$ 1,520$ each . ................... 34,960

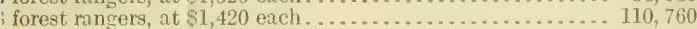

$\therefore$ : forest rangers, at $\$ 1,320$ each . . . . . . . . . . . . . . . . . . 380,160

forest rangers, at $\$ 1,220$ each ..................... 719,800

1,j total new places.

$\mathrm{Pl}$ wro 3 dropped:

1 forest supervisor............................. 3,040

1 forest supervisor............................. 2,700

8 forest supervisors, at $\$ 2,400$ each.................. 19, 200

20 forest supervisors, at $\$ 2,200$ each................... 44, 000

49 forest supervisors, at $\$ 2,000$ each........................ 98,000

66 forest supervisors, at $\$ 1,800$ each................... 118, 800

5 forest supervisors, at $\$ 1,600$ each................... 8,000

1 deputy forest supervisor........................ 1,800

4 deputy forest supervisors, at $\$ 1,700$ each............. 6,800

28 deputy forest supervisors, at $\$ 1,600$ each............. 44,800

31 deputy forest supervisors, at $\$ 1,500$ each............. 46, 500

18 deputy forest supervisors, at $\$ 1,400$ each............ 25, 200

11 forest rangers, at $\$ 1,500$ each $\ldots \ldots \ldots \ldots \ldots \ldots \ldots \ldots \ldots \ldots \ldots \ldots .16,500$

23 forest rangers, at $\$ 1,400$ each.................... 32,200

78 forest rangers, at $\$ 1,300$ each.................... 101, 400

288 forest rangers, at $\$ 1,200$ each...................... 345,600

630 forest rangers, at $\$ 1,100$ each.......................6. 693,000

100 forest guards, at $\$ 1,100$ each, for periods not exceeding six months in the agregate..................... 55,000

40 forest guards, at $\$ 1,100$ each, for periods not exceeding three months in the aggregate..................... 11, 000

1,402 total places dropped.

GENERAI, EXPENSES.

Introductory paraqraph (p. 35, line 1).-The limitation on the eost of any building erected on the national forests has heen increased from $\$ 800$ to $\$ 1,000$. 
The following new proviso has been inserted: "Provided further, That hereafter the charge for grazing permits upon each of the national forests shall be not less than the appraised value of pasturage upon such national forests as determined by the Secretary of Agriculture from time to time, but at least ever!l five years, beginning with the calendar year 1921, upon the basis of the commercial rates charged for pasturage upon lands of similar character, taking into account the advantages and disadvantrges of the respective areas: ind provided also, That the Secretary of Agriculture may allow free of charge the grazing of milch, work, or other animals used for domestic purposes not exceeding a total of ten head owned and in use by bona fide. settlers residing in or near a national forest: or animals in actual use by prospectors, campers, and travelers; or saddle, pack, and work animals actually used in connection with permitted operations on the national forests.'

The receipts from grazing during the fiseal year 1919 amounted to approximately $\$ 2,600,000$. It is estimated that the new grazing fees will practically double this sum. The testimony before the committee shows that the average rate for cattle grazing this year is $\$ 1.20$ a head for the entire year. Where the grazing is for only a few months the rate is one-tenth of the annual rate per month. The average period during which cattle have been on the forests this year is six months. The average amount collected is 72 cents per head. The sheep rate is 25 per cent of the cattle rate.

The average period the sheep have been on is about four months. The average fee collected from sheep grazing is about 12 cents per head.

Twenty-five per cent more is charged for horses than for eattle. The average rate collected for horses is about 90 cents per head.

The number of swine is very small.

The following table shows the grazing permits issued and number of stock grazed:

\begin{tabular}{|c|c|c|c|c|c|c|c|}
\hline \multirow{3}{*}{ State. } & \multicolumn{4}{|c|}{ Cattle, horses, and swine. } & \multicolumn{3}{|c|}{ Sheep and goats. } \\
\hline & \multirow{2}{*}{$\begin{array}{l}\text { Permits } \\
\text { issued. }\end{array}$} & \multicolumn{3}{|c|}{ Number of stock grazed. } & \multirow{2}{*}{$\begin{array}{l}\text { Permits } \\
\text { issued. }\end{array}$} & \multicolumn{2}{|c|}{$\begin{array}{c}\text { Number of stock } \\
\text { grazed. }\end{array}$} \\
\hline & & Cattle. & Horses. & Swine. & & Sheep. & Goats. \\
\hline Alabama. & & 59 & & & & & \\
\hline Arizona... & 1,570 & 360,011 & 6,509 & 637 & 160 & 364,853 & 6,6004 \\
\hline Arkansas........ & 452 & 4,591 & so & 49.1 & 15 & 49 & 230 \\
\hline 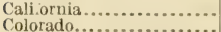 & 3,021 & 208,683 & 7,019 & 3,324 & 551 & 606,526 & 13,256 \\
\hline 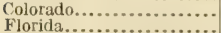 & $\begin{array}{r}4,455 \\
23\end{array}$ & 380,460 & 9,503 & $\cdots$ & 872 & $1,044,208$ & 1,322 \\
\hline Georgia......... & & 440 & 14 & $\begin{array}{r}0 \\
15\end{array}$ & 3 & & (n) \\
\hline Idaho......... & 4,213 & $190,60 \mathrm{~s}$ & 13,794 & & 1,093 & $1,758,877$ & $\cdots \cdots$ \\
\hline $\begin{array}{l}\text { Michigan.. } \\
\text { Montana.. }\end{array}$ & 2,865 & 170,674 & 16,524 & & 521 & 835,224 & $\ddot{13 i}$ \\
\hline Nebraska................. & 54 & 12,757 & 713 & (n........... & $\ldots$ & $\ldots \ldots$ & \\
\hline 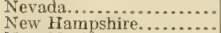 & $\begin{array}{r}502 \\
15\end{array}$ & $\begin{array}{r}77,432 \\
158\end{array}$ & $\begin{array}{r}4,320 \\
12\end{array}$ & $\cdots$ & 109 & 390,753 & 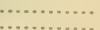 \\
\hline New Mexico................ & 2,020 & 174,979 & 5,309 & 467 & 576 & 440,302 & $39,0.51$ \\
\hline $\begin{array}{l}\text { North Carolina........... } \\
\text { Oklahoma.............. }\end{array}$ & $\begin{array}{r}186 \\
57\end{array}$ & $\begin{array}{l}1,157 \\
3,304\end{array}$ & $\begin{array}{r}52 \\
294\end{array}$ & 56 & 5 & & N...... \\
\hline Oregon ......... & 2,478 & 162004 & 10,066 & $\ddot{88}$ & 537 & 753,418 & $\dddot{5}$ \\
\hline South Dakota............. & 786 & 38,185 & 3,184 & ..... & 8 & 12,200 & $\cdots$ \\
\hline $\begin{array}{l}\text { Tennessee. ..... } \\
\text { Utah. }\end{array}$ & $\begin{array}{r}47 \\
7,249\end{array}$ & $\begin{array}{r}431 \\
172,246\end{array}$ & 9,914 & 67 & $\begin{array}{r}5 \\
1,641\end{array}$ & $\begin{array}{r}75 \\
811-510\end{array}$ & iio \\
\hline Virginia........ & 273 & $\begin{array}{r}1 / 2,240 \\
2,614\end{array}$ & 15 & ..... & $\begin{array}{r}1,041 \\
1\end{array}$ & $\begin{array}{r}811,510 \\
6\end{array}$ & \\
\hline Washington... & 1,031 & 30,743 & 2,318 & .... & 196 & 236,307 & (n....... \\
\hline Wyoming.... & 1,181 & 143,204 & 3,611 & 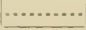 & 329 & 680,670 & 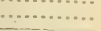 \\
\hline Total............... & 32,528 & $2,135,527$ & 93,251 & 5,154 & 6,624 & $7,935,174$ & 60,789 \\
\hline
\end{tabular}


Salaries of forest supervisors, rangers, and guards (p. 37, line 9). This appears as a new item and carries an increase of $512,5,000$. It: purpuse is to pre wi le for the salaries of part-time emplorece heretefore carried on tie statutory roll and for the employment of emererence labor incident to the adiministration of all the national forests.

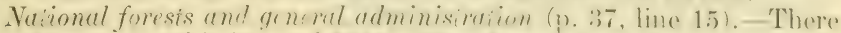
is a decrestse in this item of S439. Two formts have heren increased. the Idaho National Forest by 814 (s) atcel the Parefte National Forest by $\$ 9,350$, a total increase of 824,390 , due to the addition of the Thumder Mountain area in central Idaho, comprising 1,(1).5,022.11 acres, in accordance with the provisions of Public No. 69. Six forests have been decreased, as follows:

Colville National Forest, Washington, by $\$ 2,7 \$ 4$.

Eldorado National Forest, Califormia and Nevada, by \$2,250.

Kaniksu National Forest. Idaho and Mashington, hi $86.94: 3$.

Monterey National Forest, California!, \$.3,547, havifer heen consolidated with the Santa Barbara National Forest.

Sioux National Forest, South Dakota and Montana, hy S2,6.10, as it will be eonsolidated with the Custer National Forest during the present fiscal year.

Tusayan National Forest, Arizona, by $\$ 4,(0) 5$, a total decrease of $\$ 22,149$.

The Minam National Forest has been omited, as it is proposed to consolidate this forest with the Whitman National Forest during the current fiscal year, the latter being increased correspondingly. In addition the appropriation for use in the District of Columbia has been decreased $\$ 2,520$.

Land classification and mitry surveys (p). 45, line 12).-.-There is a decrease in this item of $\$ 20,000$. New language has heen added permitting the survey of lands involved in exchanges authorized by law.

Supplies and equipment (p. 46, line 1).--There is a decrease in this item of $\$ 11,100$.

Range investigations. - This item, amounting to $\$ 35,000$, has been omitted.

Tree planting on national forests (p. 46, line 14). -There is a decrease in this item of $\$ 25,000$. The proviso authorizing the purchase of land for a forest nursery site on the Michigan National Forest has been omitted, as the site will be purchased during the current fiscal year.

Silvicultural inestigations (p. 46, line 18).-There is a decrease in this item of $\$ 43,728$.

Reconnoissance of forest resources (p. 46, line 23).-.'There is an increase in this item of $\$ 25,000$. This amount will be required for the necessary estimating and appraising of the grazing resources of the national forests incident to the changed program provided in this bill Ifiscellaneous forest inestigations (1). 47. line 3).--There is a decrease in this item of $\$ 6,280$.

Improvement of the national forests (p. 47, line 7).-There is a decrease in this item of $\$ 50,000$. The provisos prohibiting the use of funds from this appropriation for the payment of traveling expenses except on official business and for the prepraration or publication of any newspaper or magazine article have been broalened to include all funds appropriated for the Forest service. "The word "herenfter" has also been inserted in each proviso. These provisions have heen included in the appropriation acts since 1911, and it is now proposed 
to make them permanent legislation so that it will not be necessary to repeat the language from year to year.

The following table shows the expenditures of the Forest Service during the fiscal year ending June 30, 1919:

Regular expenditures from annual appropriation:

Field expenses connected with the national forests

General expenses connected with the Washington office..........

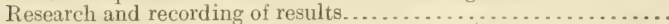

$\$ 4,801,794.67$

$472,403.22$

$388,023.68$

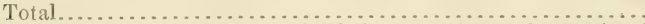

Emergency fire expenditures, derived in 1919 from the national

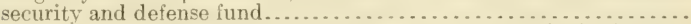

Cooperative contributions for work on national forests, including protection, improvements, and brush burning...................

Cooperation with States in fire protection outside the national forests.

Cooperative contributions from Army and Navy for military research

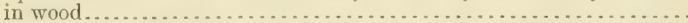

Construction of roads, from the 10 per cent fund (total available,

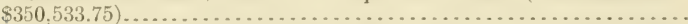

Construction of roads, section 8, Federal-aid road act and Post Office appropriation act (total available, $\$ 4,000,000)$. . . . . . . . . . . . .

Amount paid to States representing 25 per cent of gross receipts.......

Special apportionment for Arizona and New Miexico for school lands

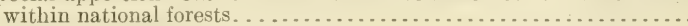

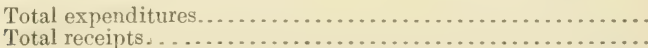

$5,662,221.57$

$650,000.00$

$522,840.05$

$99,921.13$

$372,233.81$

$279,055.63$

$548,764.80$

$1,069,886.88$

$78,687.32$

$9,285,611.19$

4, $358,414.86$

Deficit.

4, 927, 196. 33

\section{BUREAU OF CHEMISTRY.}

\section{STATUTORY SALARIES.}

(P. 48, line 21.)

The statutory roll of the Bureau of Chemistry carries an apparent increase of $\$ 14,520$, but there is an actual decrease of $\$ 1,300$, as indicated in detail in the following table:

Transfer from lump funds of this bureau, which funds have been correspondingly reduced:

2 clerks, class 4 , from food and drugs act............... $\$ 3,600$

1 clerk, from food and drugs act............................ 1,440

2 clerks, class 2 , from food and drugs act and poultry and egg

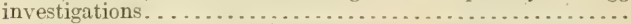

1 machine operator, from food and drugs act, with change of title.

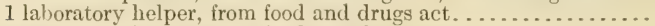

1 laboratory helper, from food and drugs act. . . . . . . . . . . . . .

1 laborer, from food and drugs act. ...........................

2 laboratory helpers or laborers, at $\$ 720$ each, from color investigations and poultry and egg investigations..............

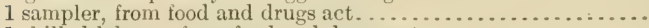

1 skilled laborer, from food and drugs act..................

1 messenger boy, from food and drugs act. . . . . . . . . . . . . .

1,000

Places dropped:

8 food and drug inspectors, at $\$ 1,400$ each. . . . . . . $\$ 11,200$

Transfer to statutory roll, Division of Publications:

1 clerk.

900

New places:

2 food and drug inspectors, at $\$ 2,000$ each . . . . . . . 4,000

2 food and drug inspectors, at $\$ 1,800$ each . . . . . . . . . . . . 3,600

2 food and drug inspectors, at $\$ 1,600$ each . . . . . . . 3, 200

10,800

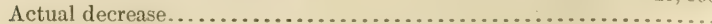

Apparent increase 


\section{GENERAL EXPENSES.}

Investigutions in aqricultural chemistry (p). 50, line 21). -This item is a combination of three existing subappropriations, (1) the application of chemistry to agriculture, (2) the biological investigation of food and drug products, and (3) the study and improrement of methods of utilizing by-products of citrus fruits. The amount carried by these three items for the current fiscal year aereregates $\$ 7(), 400$, so that the total sum prorided for the fiscal rear 1 ! $2 \mathrm{i}$ for these activities represents an actual decrease of $\$ 4,000$.

P'oultry, rgg, fish, and oyst r imestigitions (p. 51, line 7). -This item is a combination of the present subappropriations for (1) poultry and egg investigations, and (2) fish and oyster investigations, the appropriations for which agregate 865,000 . There is, therefore, an apporent decrease for this work of $\$ 12,120$, but, as 2,120 has been transferred to the statutory roll, the actual decrease is $\$ 10,000$.

color invertigations (p. 51, line 1:3). -There is an apparent decrease in this item of $\$ 31,740$, but, as $\$ 720$ ) has been transferred to the statutory roll, the actual decrease is $\$ 31,020$.

Sirup imestigations (p. 51, line 19).-There is an increase in this item of $\$ 5,000$, making the total appropriation for sirup investigations $\$ 15,000$. Of this amount the comnit tee recommends that $\$ 7,500$ be set aside for the inrestigation of the sweet potato as a source of sirup) production.

Enforcement of the food and drugs act (p. 51, line 2:3). The item for investigating the character of the chemical and physical tests applied to American food products in foreign countries, cairying an appropriation of 84,280 , has been added to the item for the enforcement of the food and drugs act, the total appropriations for both items for the current year being $\$ 624,501$. There is an apparent decrease in the total appropriation for this work of $\$ 45,140$, hut, as $\$ 15,140$ has heen transferred to statutory rolls, the actual decrease is $\$ 30,000$.

Insecticide and fungicide investigations (p. 52, line 21).--There is a decrease of $\$ 5,000$ in this item.

Dehydration investigations (p. 53, line 1). There is a decrease in this item of $\$ 26,500$.

Utilization of wool-scouring wastes (p. 53, line 6).-There is a decrease in this item of $\$ 3,000$.

\section{ENFORCEMENT OF THE TEA-IMPORTATION ACT.}

\section{(P. 53, line 9.)}

A new paragraph, (arrying an appropriation of $\$ 40,000$, has been added, providing for the transfer from the Treasury Department to the Department of Agriculture of the powers and duties relating to the administration of an act entitled "An act to prevent the impertaltion of impure and unwholesome tea, approved Warch 2, 15:9\%, as amended by the act of Mr!y 16, 1908." The logrieal place for this work is believed to be in the Department of Agriculture, and the proposed transfer has been approved by the heads of the departments concerned.

H. Rept. 596, 66-2-2 
BUREAU OF SOILS.

STATUTORY SALARIES.

(P. 54, line 14.)

The statutory roll of the Bureau of Soils carries an apparent increase of $\$ 3,900$, but there is no actual increase, as indicated in the following table:

Transfers from lump funds of this bureau, which funds have been correspondingly reduced:

1 administrative assistant, from potash investigations .............. $\$ 2,100$

1 soil cartographer, from soil survey ......................... 1,800

Apparent increase.............................. 3.900

GENER:I, EXPENSES.

Soil chemical investigations (p. 55, line 16).-There is a decrease in this item of $\$ 2,500$.

Investigation of fertilizer resources (p. 56, line 3).-There is an increase in this item of $\$ 5,500$, which is to be used for the development of phosphate fertilizer resources. Phosphate rock and phosphate fertilizer investigations have been confined largely during the past year to furnace treatment of phosphate rock. 'The process in course of development has for its object the production of highly concentrated phosphoric acid and phosphate fertilizers from low-grade raw materials. This process also gives promise of conserving vast quantities of phosphate materials now thrown away or lost in the present systems of mining and preparing the rock for the market. The preliminary work accomplished has been highly satisfactory, and a modified blast furnace of semicommercial size is in course of construction. It is anticipated that the results will furnish data from which it will be possible to determine the cost of producing phosphate fertilizer by the new process. From time to time it will be necessary to run this plant continuously for protracted periods, requiring two or three shifts of men, thereby necessitating additions to the present force. Repairs and changes must also be made as the work progresses.

Soil survey investigations (p. 56, line 6).-There is an apparent decrease in this item of $\$ 19,300$, but, as $\$ 1,800$ has been transferred to the statutory roll, the actual decrease is $\$ 17,500$.

Classification of agricultural lands (p. 56, line 12).-There is a decrease in this item of $\$ 3,100$.

Potash investigations (p. 56, line 16).-There is an apparent increase in this item of $\$ 65,300$, but, as $\$ 2,100$ has been transferred to the statutory roll, the actual increase is $\$ 67,400$. This amount is necessary in order to provide for new apparatus, additional supplies, acid for char extraction, and to meet the advance in the cost of labor in operating the experimental kelp potash plant at Summerland, Calif. It is estimated that $\$ 101,000$ will be realized from the sale of products at this plant for the current fiscal year. For the fiscal year 1921 it is believed that the receipts will more than cover all expenses, including the heavy overhead now entailed by a large and expensive force of chemists, engineers, and construction and repair men. 
Following is an estimate of receipts for 1921 on the basis of 300 days of operation:

150 units of potash per day, at $\$ 2$ per unit........................ $\$ 90,000$ 1 ton of cark on per day, at $\$ 300$ per ton ................................. $\$ 90,000$ 20 pounds of iodine per day, at $\$ 4$ per pound......................... 24.000 1.600 pounds of sulphate of ammonia per day, at $\$ 4$ per hundredweight..... 19,000

The results so far obtained indicate that the production of potash from kelp can be made a commercial success, hut a number of questions need more complete inrestigation before the matter can he finally submitted to the public. This will take at least another year. It has been demonstrated that not less than $500,000($ tons of raw kelp per annum are arailable in the vicinity of the department's plant at Summerland. It is assumed, therefore, that, if it is conclusively shown what profits are obtainable from the treatment of kiclp by the process dereloped by the departmeni, plants will be established sufficient in capacity to utilize the raw material available. The benefit to the public, therefore, from the successful outcome of these experiments seems to be assured and certainly justifies the appropriation recommended.

\section{BUREAU OF ENTOIMOLOGY.}

\section{STATUTORY SALARIES.}

(P. 57, line 4.)

The statutory ro!l of the Bureau of Entomology carries an apparent increase of $\$ S, S 00$, but there is an actual decrease of $\$ \$(10)$, as indicated in detail in the following table:

Places dropped:

7 entomological preparators, at $\$ 600$ exch....................... $\$ 4,200$ New places:

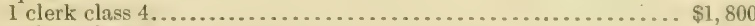

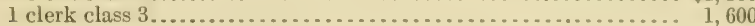

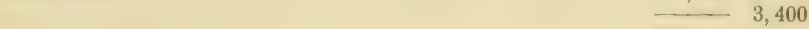

Actual decrease.................................... 800

Transfers from lump funds of this bureau, which funds have been correspondingly reduced:

2 clerks class 3 , from truck crop insects................. $\$ 3,200$

2 clerks class 2,1 from cereal and forage insects and 1 from pre-

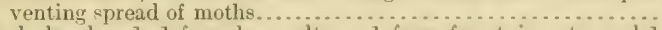

3 clerks class 1, 1 from bee culture, 1 from forest insects, and 1 from deciduous fruit insects........................ 3,600

Apparent increase............................. 8,800

GENERAL EXPENSES.

Deciduous fruit insect investigations (p. 5s, line 10).-There is an apparent increase in this it $\mathrm{cm}$ of $\$ 72,720$, but, as 82,280 has been transferred to statutory rolls, the actual increase is $\$ 75,000$. This additional amount will be used for extending the work in the control of the Japanese beetle. The allotment for this work under the present appropriation is $\$ 25,000$, which with $\$ 30,000$ to be made 
immerliately araitable provides a total of $\$ 55,000$ for this purpose during the fiscal year 1920 . The remaining $\$ 45,000$ of the increase; together with $\$ 25,000$ allotted for the control of the Japanese beetle from the present appropriation, will make $\$ 70,000$ arailable for combating this pest during the next fiscal year.

The Japanese beetle, introduced from Japan, has become in this country a serious enemy of many kincis of plants, including orchards, rineyarls, truck crops, omamental plants, various weeds, shade trese, ste. It is now establi hed in Burlington and Camden Counties, N. J., and covers an area, according to present surveys, of about 15,000 acres. It is extremely important that everything f(a ibl. be done to prevent the further spread of this insect, and it is belised that money expendid in this work will he a very profitable investment because it will protect other parts of the country from the ravages of the insect and obviate th necesity for considerable larger expenditures in connection with control measures over much rreater areas.

('ereal and forage insect investigations (p. 5s, line 15).-There is an apparent decrease in this item of $\$ 1,400$, but, as that amount has bern transferred to the statutory roll, there is no actual change.

The committee recommends that $\$ 20,000$ of the amount carried by thic item be used for the extension of alfalfa weevil investigations

control of the European cornborer.-This item has been omitted pending action by Congress on the deficiency estimate for $\$ 500,000$ covering this work which has recently been submitted by the department.

Southern field-crop insect investigations (p. 58, line 18).-There is an increase in this item of $\$ 24,600$, which is desired for extending the experiments for the control of the cotton-boll weevil. The possibility of practical control of the weevil in the Mississippi Delta region by the use of calcium arsenate in dust form has been demonstrated. In some instances the per acre yield of cotton has been doubled by the application of this insecticide. New types of both hand and power machines for applying the poison have also been developed. Further improvement in both poison and machines in the interest of economy is poscible, and investigations to this end should be made.

Forest-insect investigations (p. 58, line 23).-There is an apparent decrease in this item of $\$ \$, 790$, but, as $\$ 1,200$ has been transferred to the statutory roll, the actual decrease is $\$ 7,590$.

Truck-crop and stored-products insect investigations (p. 58, line 24).There is an apparent decrease in this item of $\$ 24,960$, but, as $\$ 3,200$ has been transferred to the statutory roll, the actual decrease is $\$ 21,760$. The committee recommends that $\$ 10,000$ of the total appropriation be used for the investigations of the grain moth.

Bee culture investigations (p. 59, line 4).-There is an apparent decrease in this item of $\$ 1,200$, but, as this amount has been transferred to the statutory roll, there is actually no change.

Investigations of tropical and subtropical plunt insects (p. 59, line 6).The item is a combination of three existing appropriations, (1) investigations of insects affecting tropical and subtropical fruits, (2) investigations and control of the Mediterranean and other fruit flies, and (3) investigations of the camphor thrip. It involves a net decrease of $\$ 2,000$. 
Mriscellaneous insect investigations (p. 59, line 9).-There is a decresse in this item of $\$ 10,000$.

Administrative cxpenses (p. 59, line 14). - There is a derease in this item of $\$ 1,600$.

\section{PREVENTING SPREAD OF MOTHS.}

(P. 59, line 18.)

There is an apparent decrease in this item of $\$ 104,050$, but, as $\$ 1,400$ has been transferred to the statutory roll, the actual decrease is $\$ 102,650$.

\section{BUREAU OF BIOLOGICAI SURVEY.}

\section{STATUTORY SALARIES.}

\section{(P. 60, line 17.)}

The statutery roll of the Bureau of Biological Survey earries an apparent increase of $\$ 12,900$, but there is no actual increase, as indicated in detail in the following table:

Transiers from lump funds of this bureau, which funds have been correspond-

ingly reduced:

2 clerks, class 4, 1 from food habits of birds and mammals and 1 from pro-

tection of migratory birds.................................. $\$ 3,600$

1 clerk, from game preservation ............................ 1,500

3 clerks, class 2, 2 from food habits of birds and mammals and 1 from sup-

pression of rabies .................................. 4, 200

3 clerks, class 1, 2 from food habits of birds and mammals and 1 from pro-

tection of migratory birds............................... 3,600

Apparent increase ...............................

\section{GENERAL EXPENSES.}

Sullys IIill game presere (p. 61, line 24).-The language of this paragraph has been amended by inserting the words "and maintenance" after the word "improvement" and by chancring the word "preserves" to "preseme." There is only one gamo preserve in the Sullys Hill National Park. The present language limits the expenditure of funds under this paragraph to improrement work. It present the maintenance of the preserve is paid for from the appropriation for the general maintenance of reserrations and is an additional charge on that fund. The paragraph carried in the appropriation act for 1918 provided for the "maintenance and improvement" of the Sullys Hill game preserve. It is believed to be a more satisfactory arraingement to have both the improvement and maintenance work provided for under one item. It is proposed to use from $\$ 1,500$ to $\$ 2,000$ of this appropriation for maintenance and the balance for improvement work.

Food habits of birds and mammals (p. 62, line 6).-. There is an apparent decrease in this item of $\$ \$, 400$, but, as that amount has been transferred to the statutory roll, there is actually no change. This paragraph has been revised in order to clarify the language.

Enforcement of the migratory-lirel treaty act (p. 62, line 20). - There is an apparent decrease in this item of $\$ 4,500$, but, as that amount has been transferred to the statutory roll, there is actually no change. 
licinder investigations and protection of land fur-bearing animals in Alestar (p. 63, line 10). - This is a new item and carries an appropriation of $\$ 40,000$. It provides for investigation, experiments, and demonstrations for the welfare, improvement, and increase in the reindeer industry in Alaska, in eopperation with the Burcan of Eilucation: for t!re ('nforeement of section 956 of the Revised statutes so far as it relates to the protection of land fur-bearing aninals in Mlaska; and for the transfer from the Department of Commerce to the Department of Agriculture of the powers and duties with respert to the protection of land fur-bearing animals, which transfer has the approval of the heads of the departments concerned. Of this appropriation $\$ 25,000$ is to be used for the reindeer and $\$ 15,000$ for the fur-bearing animals.

The first lot of reindeer in Alaska, numbering 171, was imported from Siberia in 1592 . It is estimated that that number has increased to about 200,000 at the present time, and that through the proper devclopment of the industry it may be increased to $10,000,000$. The building up of the reindeer herds into larger animals producing more meat can be readily brought about by capturing wild caribou bulls in interior Alaska and using them to grade up the domestic animals. This it is proposed to do with a portion of the appropriation, and also to investigate several diseases reported to occur among reindeer, as it will readily be seen that a serious outbreak of some contagious disease might have disastrous effects on the industry, which has grown to be one of the chief sources of food in that northern country.

\section{DIVISION OF ACCOUNTS AND DISBURSEIENTS.}

\section{STATUTORY SALARIES.}

(P. 65, line 2.)

The statutory roll of the Division of Accounts and Disbursements carries an increase of $\$ 3,600$, as indicated in the following table:

New places:

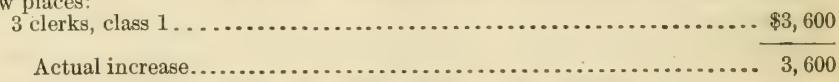

\section{DIVISION OF PUBLICATIONS.}

\section{STATUTORY SALARIES.}

(P. 65, line 13.)

The statutory roll of the Division of Publications carries an increase of $\$ 46,950$, as indicated in detail in the following table:

New places:

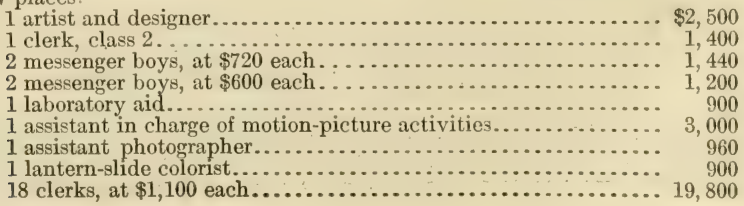


New places-Continued.

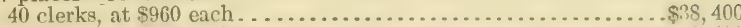

15 clerks, at $\$ 900$ each . . . . . . . . . . . . . . . . . . . . . . . . . . . . . . . 13,500

1 folder........................................... 1,200

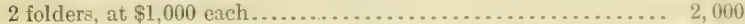

6 skilled laborers, at $\$ 1,100$ each $\ldots \ldots \ldots \ldots \ldots \ldots \ldots \ldots \ldots .6,600$

Places dropped:

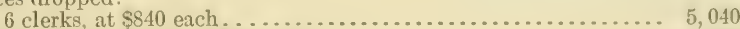

2 messenger boys, at $\$ 480$ each ................................... 960

2 messenger boys, at $\$ 420$ each ........................ 840

2 messenger boys, at $\$ 360$ each . ........................ $\quad 720$

1 laboratory aid............................................

1 assistant photographer............................. 900

1 lantern-slide colorist.............................. 840

18 clerks, at $\$ 1,000$ each ................................. 18, 000

40 clerks, at $\$ 900$ each................................... 36,000

15 clerks, at $\$ 840$ each............................... 12,600

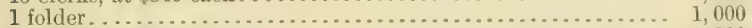

2 folders, at $\$ 900$ each .............................. $], 800$

6 skilled laborers, at $\$ 1,000$ each........................... 6,000

Transfers from funds of other bureaus, which funds have been correspondingly reduced:

1 assistant in charge of exhibits, from statutory roll, Secretary's office, with change of title............................ $\$ 3,000$

1 assistant in charge of information, from statutory roll, Secretary's

1 assistant in charge of motion-picture activities, from general

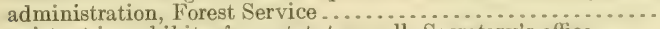

1 assistant in exhibits, from statutory roll, Secretary's offico......

1 assistant, from statutory roll, Secretary's office..............

1 assistant editor, from statutory roll, Secretary's office.........

3 assistant editors, at $\$ 1,800$ each, from statutory roll, Secretary's

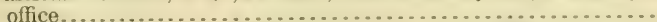

1 assistant editor, from statutory roll, Secretary's office ..........

1 clerk, class 4, from statutory roll, Secretary's office, with change

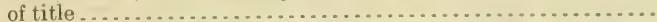

4 clerks, class 2 , from statutory roll, Secretary's office...........

4 clerks, class 1 , from statutory roll, Secretary's office...........

2 clerks, at $\$ 1,000$ each, from statutory roll, Secretary's office....

1 messenger or laborer, from statutory roll, Secretary's office, with

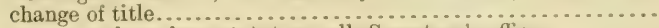

1 messenger boy, from statutory roll, Secretary's office..........

2 messenger boys, at $\$ 480$ each, from statutory roll, Secretary's

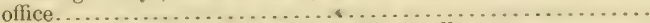

1 charwoman, from extra labor, Secretary's office .............

Actual increase.

\section{GENERAL EXPENSES.}

Labor-saving machinery (p. 67, line 1).-There is an increase in this item of $\$ 1,000$. This amount will be used for the purchase of additional equipment and supplies necessitated by the centralization in this division of the duplicating and automatic addressing work of the department as a whole and the consequent increase in such work by the Division of Publications.

Stationery and materiats (p. 67, line 3).-There is an apparent increase in this item of $\$ 1,500$, but this merely provides for the transfer of that amount from the appropriation for "Miscellaneous 
Expenses," which fund has been correspondingly reduced. It represents the amount that has been allotted from this appropriation to the ()ffice of Information during the fiscal year 1920 for the purchase of paper and envelopes. With the merging of this office with the Division of Publications, it will simplify the accounting and add to the convenience of administering expenditures to have this transfer of funds made.

Photographic equipment (p. 67, line 5).-The word hereafter has been added in the proviso so as to make the authority to loan, rent, or sell films permanent legislation.

Ifiscellaneous expenses (p. 67, line 19).-There is an increase in this item of $\$ 350$, which amount is necessary to provide for miscellaneous expenses of the Office of Information heretofore paid from the appropriation "Miscellaneous Expenses," and to meet the general advance in the cost of all items coming within the scope of this appropriation.

Agricultural exhibits (p. 67, line 22). -This item has been transferred from the miscellaneous section of the bill and the amount decreased rom $\$ 100,000$ to $\$ 70,000$. The exhibit work is a valuable means of bringing the latest developments in agriculture directly to the public, and many thousands of people are reached in this way who would not otherwise come in touch with the results of the department's work. Exhibits were shown at 57 fairs and expositions this year.

The clause regarding the National Dairy Show at Chicago, Ill., has been omitted, as this has reference to the show which took place during the fiscal year 1920, but an exhibit similar to the one this year will be provided next year. The provision fixing at $\$ 5,000$ the maximum expenditure that may be incurred in connection with any one fair also has been omitted, so as to leave the apportionment of funds discretionary with the department, to be determined by the requirements in each case.

The following language has also been added to the paragraph: "in cooperation with other departments of the Government."

Emergency employments (p. 68, line 1).-There is an increase in this item of $\$ 15,000$. This amount will be required for the employment of emergency laborers and assistants in comnection with the preparation of the agricultural exhibits mentioned in the preceding item.

\section{BUREAU OF CROP ESTIMATES.}

\section{STATUTORY SALARIES.}

\section{(P. 68, line 6.)}

The statutory roll of the Bureau of Crop Estimates carries an increase of $\$ 240$, as indicated in the following table:

Transfer from lump fund for extra labor, Secretary's office, which fund
has been correspondingly reduced:

1 charwoman ........................................ $\$ 240$

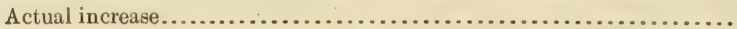


(GENERAJ, EXPENSES.

Introluctory faragreph (p. 6s, line 15). - The language of this paragraph has been amended by the addition of the words " in conperation with the States Retationis Somice." The committer believes that the county agents should he utilized in estimating (rops.

Firld investigations (p. 69, line 1).-There is a decrease in this item of $\$ 48,486$.

LIBRARY, DEPARTMENT OF AGRICULTURE.

STATUTORY SALARIES.

(P. 69, line 7.)

The statutory roll of the Library carries an apparent increase of $\$ 720$, but there is an actual decrease of $\$ 1 \$ 0$, as indicated in the following table:

Transfer from lump fund for general expences, which fund has been correspondingly reduced:

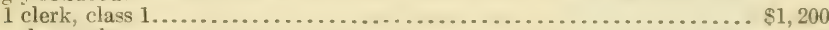

Place dropped:

1 messenger boy ..................................... $\$ 480$

Actual decrease....................................... 480

Apparent increase. ................................... $\quad \overline{720}$

GENERAL EXPENSES.

(P. 69, line 14.)

There is no apparent change in this item, but, as $\$ 1,200$ has been transferred to the statutory roll, the actual increase is $\$ 1,200$.

MISCELLANEOUS EXPENSES.

(P. 69, line 23.)

There is an apparent decrease in this item of $\$ 39,500$. This decrease is due in part to the elimination of the prorision of $\$ 33,000$ for repairs to the department's power plant, which repairs will be made during the current fiscal year, and the transfer to the Division of Publications of $\$ 1,500$ heretofore allotted from this appropriation for the purchase of envelopes and miscellaneous supplies in comnection with the informational and exhibit work of the department, which it is proposed to merge with the Division of Publications.

\section{RENT IN THE DISTRICT OF COLUMBIA.}

$$
\text { (P. 70, line 16.) }
$$

There is an apparont increaso in this item of $\$ 64,666$. This amount includes the transfer of the $\$ 41,509$ item for rent carried in the sundry civil act for the current fiscal year, and $\$ 14,666$ to eover items for rent that are now being paid from certain lump funds of the department. The committee has eliminated from these lump funds the 
authority for the payment of rent in the District of Columbia, and its action in transferring to this item the amounts carried in the Agricultural act which are used for the payment of rent effects a consolidation in one paragraph of all items for the rental of additional office space in the District of Columbia for the next fiscal year which can not he furnished by the Public Buildings Commission in Government buildings.

\section{STATES RELATIONS SERVICE.}

STATUTORY SALARIES.

(Page 71, line 2.)

The statutory roll of the States Relations Service carries an apparent increase of $\$ 32,000$, but there is no actual increase, as indicated in detail in the following table:

Transfers from lump funds of this bureau, which funds have been correspondingly reduced:

1 clerk, class 4, from farmers' cooperative demonstrations in North and West................................ $\$ 1,800$

1 executive clerk, from home economics........................ 1,740

4 clerks, class 2, from farmers' cooperative demonstrations in North and West.

16 clerks, class 1, 4 from colleges and stations and 12 from farmers' cooperative demonstrations in North and West.............. 19, 200

1 clerk or artist-draftsman, from farmers' cooperative demonstrations in North and West............................. 1,200

1 clerk or machine operator, from farmers' cooperative demon-

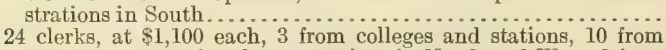
farmers' cooperative demonstrations in North and West, 8 from farmers' cooperative demonstrations in South, 2 from farmers' institutes and agricultural schools, and 1 from general adminis-

trative expenses................................................................
1 messenger boy, from farmers' institutes and agricultural schools.

5 charwomen, at $\$ 240$ each, 2 from farmers' cooperative demonstrations in North and West, 1 from farmers' cooperative demonstrations in South, 1 from farmers' institutes and agricultural schools, and 1 from home economics..................... 1,200

Places dropped:

25 clerks, at $\$ 900$ each.

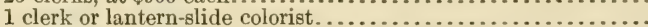

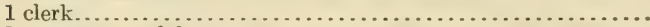

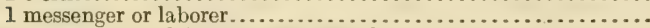

2 messengers or laborers, at $\$ 480$ each......................

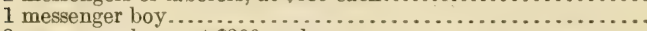

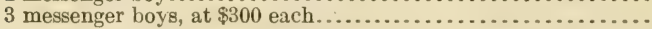

Actual decrease................................. 26, 940

Apparent increase ................................. $\overline{32,000}$

GENERAL EXPENSES.

Administration of the Hatch, Adams, and agricultural extension acts (p. 72, line 11).-There is an apparent decrease in this item of $\$ 8,100$, but as that amount has been transferred to the statutory roll, there is actually no change.

Farmers' cooperative demonstrations outside of the cotton bett (p. 73, line 9).-There is an apparent decrease in this item of $\$ 35,560$, but 
as that amount has been transforrerl to statutory rolls, there is actually no change.

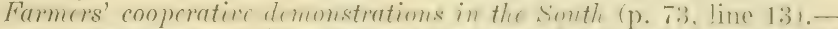
There is an apparent dererase in this itcun of 810,240 , hut as that amount has been transferred to the statulory roll, there is no ate tual change.

S'upplementary S'mith-Lever apponpriation. (p). 7:3, line 24). Thiere is no change in the amome of t'is item. IIorever, the followine table shows that there will be avaibabe durine t e next fiscal rear under t.:e Smith-Lever act $850(0,0)(0)$ more that during tire rurrent year:

Statement showing the Federa appropriations for extension work, also funds reauired to be off set by States, for the fiscal year 1921.

Federal funds:

Smith-Lever Act $\left(\$ 500,000\right.$ increase over fiscal year 1920) ......... ${ }^{1} \$ 3,580,000$

Appropriation carried in Agricultural act to supplement Smith-Lever

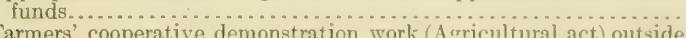

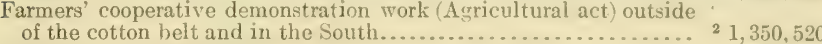

Offset required of States ............................... $4,600,000$

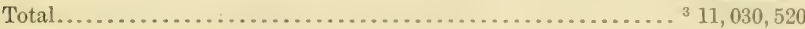

The following table shows the allotment of Federal and state extension funds by lines of work, 1919-20:

\begin{tabular}{|c|c|c|c|c|c|c|c|c|}
\hline \multirow{3}{*}{ Project. } & \multirow{3}{*}{$\begin{array}{c}\text { Farmers' } \\
\text { coopera- } \\
\text { tive } \\
\text { demon- } \\
\text { stration } \\
\text { work. }\end{array}$} & \multicolumn{5}{|c|}{ Smith-Lever, 1919-20. } & \multirow{3}{*}{$\begin{array}{l}\text { Mfiscel- } \\
\text { laneous } \\
\text { funds } \\
\text { not used } \\
\text { as offset } \\
\text { to } \\
\text { Federal } \\
\text { funds. }\end{array}$} & \multirow{3}{*}{ Total. } \\
\hline & & \multicolumn{2}{|c|}{ Regular. } & \multicolumn{2}{|c|}{ Supplementary. } & \multirow{2}{*}{ Total. } & & \\
\hline & & Federal. & State. & Federal. & State. & & & \\
\hline $\begin{array}{l}\text { County agent ......... } \\
\text { Home demonstration } \\
\text { Club work............ } \\
\text { Specialists .......... } \\
\text { Publications .......... } \\
\text { Administration....... }\end{array}$ & $\begin{array}{r}\$ 590,462 \\
279,918 \\
130,844 \\
36,000 \\
\ldots \ldots, \ldots 1 \\
15,601\end{array}$ & \begin{tabular}{|r|}
$\$ 1,079,785$ \\
521,024 \\
186,774 \\
749,047 \\
89,939 \\
453,431
\end{tabular} & $\begin{array}{r}\$ 1,041,566 \\
441,413 \\
153,147 \\
625,537 \\
73,023 \\
262,314\end{array}$ & $\begin{array}{r}\$ 901,232 \\
311,714 \\
121,652 \\
10,272 \\
2,000 \\
11,727\end{array}$ & 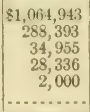 & $\begin{array}{r}84,087,526 \\
1,595,544 \\
496,558 \\
1,443,192 \\
166,962 \\
727,472\end{array} \mid$ & $\begin{array}{r}3.7,71,609 \\
696,263 \\
232,222 \\
792,400 \\
40,095 \\
171,277\end{array}$ & $\begin{array}{r}87,429,596 \\
2,571,725 \\
859,624 \\
2,271,592 \\
207,057 \\
914,350\end{array}$ \\
\hline Total.. & $1,052,825$ & $3,080,000$ & $2,600,000$ & $1,418,627$ & $1,418,627$ & $8,517,254$ & $4,683,865$ & $14,253,944$ \\
\hline $\begin{array}{l}\text { Washington supervi- } \\
\text { sion................ } \\
\text { Field service ......... } \\
\text { Envelopes . . . . . . . }\end{array}$ & $\begin{array}{r}99,340 \\
209,155 \\
35,000\end{array}$ & & & $\begin{array}{l}\cdots \ldots \ldots \\
\ldots \ldots \ldots \\
\ldots \ldots \ldots \\
\cdots\end{array}$ & $\begin{array}{ll}\ldots \ldots \ldots \\
\ldots \ldots \ldots \\
\cdots \ldots \ldots\end{array}$ & $\mid \begin{array}{l}\cdots \ldots \ldots \\
\ldots \ldots \ldots \ldots \\
\ldots \ldots \ldots \ldots\end{array}$ & & \\
\hline $\begin{array}{c}\text { Total farmers' } \\
\text { cooperative } \\
\text { demonstration } \\
\text { work............ }\end{array}$ & $1,396,320$ & & & & & & & \\
\hline
\end{tabular}

1 This includes $\$ 751,280$ for work in 33 Northern and Western States and $\$ 645,040$ for work in 15 Southern States.

Farmers' institutes and agricultural schools (p. 74, line 14).-There is an apparent decrease in this item of $\$ 4,240$, but, as $\$ 3,040$ has been transferred to the statutory roll, there is actually a decrease of $\$ 1,200$.

1 States not required to oflset $\$ 80,000$ of this amount.

2 Requirement for oliset of this amount by States left diseretionary with the Secretary of Agrienlture.

3 Exclusive of amounts contributed by states in addition to smith-Lever offsuts, and fincls cintributed by counties, local organizations, and miscollaneous sources. As county agonts are now beated in 2,000 counties, the average amount allotted to each county from this fund for exteusion work is $\mathbf{3 5 , 5 1 5 .}$ 
Insular experiment stations (p. 75, line 1).-There is a decrease in this item of $\$ 10,000$, which is accounted for by a reduction in the appropriation for the Guam experiment station. Of the $\$ 75,000$ for the Alaska experiment stations, $\$ 11,800$ has been made immediately available for the erection of necessary buildings and the purchase of breeding live stock, in comnection with the stock breeding experiments on the island of Kodiak and at the Matanuska station. This is an increase over the amount provided for the current fiscal year of $\$ 1,800$.

The proviso granting leaves of absence to employees on duty at insular stations has been eliminated as it is permanent legislation.

Home economics investigations (p. 75, line 21).-There is an apparent decrease in this item of $\$ 1,980$, but, as that amount has been transferred to the statutory roll, there is actually no change.

Administrative expenses (p. 76, line 5).-There is an apparent decrease in this item of $\$ 1,580$, but, as $\$ 1,100$ has been transferred to the statutory roll, there is actually a decrease of $\$ 480$.

\section{BUREAU OF PUBLIC ROADS.}

\section{STATUTORY SALARIES.}

(P. 76, line 14.)

The statutory roll of the Bureau of Public Roads carries an apparent increase of $\$ 4,260$, but there is an actual decrease of $\$ 2,500$, as indicated in detail in the following table:

Transfers from lump funds of this bureau, which funds have been correspondingly reduced:

1 clerk, class 3 , from road building and maintenance............ $\$ 1,600$

1 clerk, from road building and maintenance............................

1 mechanic, from road building and maintenance................... 2,100

1 skilled laborer or mechanic, from road management................ 840

1 telephone operator, from road building and maintenance............... 720

6,760

Place dropped:

1 editor ......................................... $\$ 2,500$

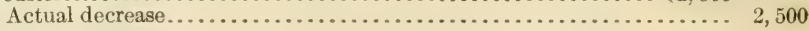

Apparent increase ............................... 4,260

\section{GENERAL EXPENSES}

Road-management investigations (p. 78, line 3).-There is an apparent decrease of $\$ 2,040$ in this item, but as $\$ 840$ has been transferred to statutory rolls there is actually a decrease of $\$ 1,200$.

Road-building and maintenance investiqations (p. 78, line 6).-There is an apparent decrease in this item of $\$ 35,920$, but as $\$ 5,920$ has been transferred to the statutory roll there is an actual decrease of $\$ 30,000$, which has been added to the item for road-material investigations.

Road-material investigations (p. 78, line 10).--There is an increase in this item of $\$ 30,000$. This amount has been deducted from the item for road building and maintenance. In the suddenly expanding program of new roar construction the highway engineer is facing the problem of road design without adequate data from which to form definite conclusions as to the types, the strength, or the 
materials which can be most of minally used. Motor-elriven traffic has now beeome the chicef factor in determining the services that will be required of our highways, and the rapiclity with which this character of traffic has developed has not permitteil the gradual evolution of road types, as was the case with the prevailing road types developed to take care of the animal-elrawn traffic. With the suddenly revolutionized methods of highway transp) rtation, road surfaces which were adequate under former ilemands are failing to meet the greatly increased numbers and weights of motor vehiches. At the same time the cost of highway construetion has materially increased. Highway construction, it is apparent, will he one of the greatest public actirities which has ever been undertaken, and appropriations running into the hundreds of millions of dollars have already been made to finance that large prosiram. The increased appropriation requested under this item will provide for conducting a comprehensive series of lahoratory and fich tests designed to give information which will permit of the selection of the right type and right design of road to economically serve the purpose for which intended. It is prisposed to conluet a large number of such experiments, in cooperation with the various State highway departments. A part of the increase will also be needed to provide additional testing equipment and employ additional assistance to take care of the increased volume of routine testing and research work in the WTashington lalorat ry. The language in the paragraph has heen amended so as to indicate more clearly the character of work contemplated.

Ficld erperiments.-The item of $\$ 60,000$ for conducting field experiments and l,uilding experimental roads has been omitted.

Farm irrigation (p. 75 , line 15). -There is a decrease in this item of $\$ 20,000$.

Farm drainage (p. 79, line 1 ).-There is a decrease in this item of $\$ 20,000$.

\section{BUREAU OF MARKETS.}

\section{STATUTORY SAIAARES.}

(P. 80, line 9.)

The statutory roll of the Bureau of Markets carries an apparent increase of $\$ 43,320$, but there is an actual decrease of $\$ 20,800$, as indicated in detail in the following table:

Transfers from lump funds of this bureau, which funds have been correspondingly reduced:

1 executive clerk, $\$ 2,000$, from market inspection of perishable

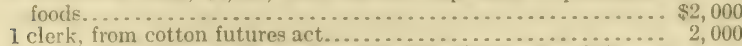

1 clerk, class 3 , from collecting and distributing market informa-

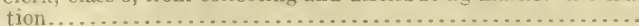

25 clerks, at $\$ 1,100$ each, 8 from collecting and distributing market information, 1 from market reports on live stock and meats, 2 from dairy and poultry products, 3 from grain, hay, feed, and seeds, 1 from food supply investigations, 1 from market inspection of perishable fouds, I from cotton testing. I from State cooperation in marketing, 1 from grain standardization, 2 from cotton futures act, and 4 from grain standards act.............

7 clerks, at $\$ 1,000$ each, 3 from marketing and distributing farm
products, 2 from dairy and poultry products, 1 from food supply

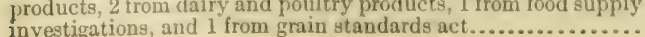


Transfers from lump funds of this bureau, etc.-Continued.

1 custodian, from grain standardization................. $\$ 1,200$

1 draftsman, from grain standardization ............................... 1,000

10 machine operators, at $\$ 1,000$ each, 1 from marketing and distributing farm products, 1 from collecting and distributing market information, and 8 from market reports on live stock

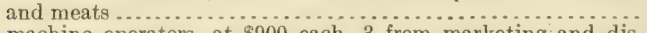

7 pachine operators, at $\$ 900$ each, 3 from marketing and distributing farm products, 2 from collecting and distributing
market information, 1 from dairy and poultry products, and 1 from grain standards act...............................

1 skilled laborer, from grain, hay, feed, and seeds...............

3 messengers, at $\$ 900$ each, 1 from marketing and distributing farm products and 2 from collecting and distributing market

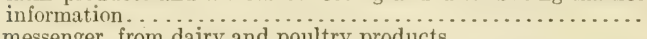

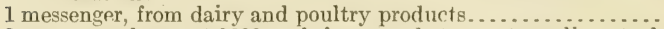

2 messenger boys, at $\$ 600$ each from market reports on live stock and meats, and dairy and poultry products.............. 1,200

Places dropped:

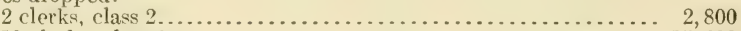

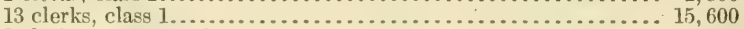

2 clerks, at $\$ 720$ each. . . .................................. 1,440

1 messenger................................... 480

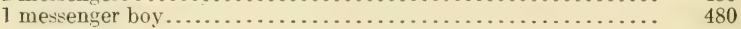

Actual decrease ............................... 20,800

Apparent increase.................................. 43,320

GENERAL EXPENSES.

Marketing and distributing farm products (p. 82, line 7).- There is an apparent decrease in this item of $\$ 41,540$, but, as $\$ 7,600$ has been transferred to the statutory roll, there is an actual decrease of $\$ 33,940$. A proviso has been added setting aside $\$ 25,000$ of this appropriation for the development of markets in the South American countries for agricultural products of the United States, chiefly live stock, by sending representatives to South America.

Regulation of stockyards.-This item, carrying an appropriation of $\$ 75,000$, has been omitted.

Market news service on live stock and meats (p. 82, line 18).-There is an apparent decrease in this item of $\$ 16,000$, but, as $\$ 9,700$ has been transferred to the statutory roll, there is actually a decrease of $\$ 6,300$.

Market news services (p. 83, line 11).-This item represents a combination of the items for market news service on (1) fruits and vegetables, (2) peanuts, (3) dairy and poultry products, and (4) grain, hay, feeds, and seeds, aggregating $\$ 392,600$ for the current year. The apparent decrease is $\$ 78,000$, but, as $\$ 25,620$ has been transferred to the statutory roll, there is an actual decrease of $\$ 52,380$.

Food supply investigations (p. 83, line 17).-There is an apparent decrease in this item of $\$ 3,180$, but, as that amount has been transferred to statutory rolls, there is actually no change.

Food products inspection service (p. 83, line 24). - There is an apparent decrease in this item of $\$ 8,300$, but, as $\$ 3,100$ has been transferred to the statutory roll, there is an actual decrease of $\$ 5,200$.

Cotton standardization investigations (p. 84, line 12). - There is an apparent decrease in this item of $\$ 5,920$, but, as $\$ 1,100$ has been transferred to the statutory roll, the actual decrease is $\$ 4,820$. 
Rural cooperation.- This item, carrying an appropriation of $\$ 15,780$ for studies of cooperation among farmers in the Tnited States, has been omitted.

State cooperation in marketing work (p. 84, line 21).--There is an apparent decrease in this item of $\$ 37,750$, but, as $\$ 1,100$ has been transferred to the statutory roll, the actual decrease is $\$ 36,650$.

Grain standardization investigations (p. 85, line 1).-There is an apparent decrease in this item of $\$ 14,900$, but as $\$ 3,300$ has been transferred to the statutory roll there is an actual decrease of $\$ 11,600$.

Enforcement of the United States cotton-futures act (p. 85, line 16).There is an apparent increase in this item of $\$ 10,831$, but as $\$ 5,280$ has been transferred to statutory rolls, and $\$ 7,689$ to the item for rent in the District of Columbia, the actual increase is $\$ 23,800$. In addition, salaries aggregating $\$ 6,100$ have been transferred from the appropriation for the wheat guaranty act for work in connection with the classification of cotton, making a total increase of $\$ 29,900$. Inasmuch as the wheat price guaranty act of March 4, 1919, contained amendments to the cotton-futures act, to carry out the purposes of which an allotment of $\$ 100,000$ was set aside by the President from the funds provided for administration of the wheat price guaranty act, the amount for the enforcement of the cotton-futures act during 1921 represents an actual decrease of $\$ 70,100$ in the funds a railable for this work.

The language of this paragraph has been amended by inserting the words " as amended March 4, 1919," after the words " United States cotton-futures act," in order to show specifically that the amendments contained in the wheat price guaranty act of March 4, 1919, are to be included among the provisions to be enforced under this paragraph.

A prorision has been added to recognize and make permanent legislation the amendments to section 6 of the act of March 4, 1919.

Enforcement of the United States grain standards act (p. 86, line 4).There is an apparent decrease in this item of $\$ 59,977$, but as $\$ 6,300$ has been transferred to the statutory roll and $\$ 6,377$ has been transferred to the item for rent in the District of Columbia the actual decrease is $\$ 47,300$.

A proviso has been added amending section 6 of the grain standards act by striking out of the last sentence the words "made after the parties in interest have had opportunity to be heard."

Administration of the warehouse act (p. 86, line 14).-There is an apparent decrease in this item of $\$ 10,600$, but as $\$ 600$ has been transferred to the item for rent in the District of Columbia the actual decrease is $\$ 10,000$.

Completion of wool work (p. S6, line 21).-This item has been decreased from $\$ 35,000$ to $\$ 15,000$.

\section{ENFORCEMENT OF THE INSECTICIDE ACT.}

STATUTORY SALARIES,

(P. 87, line 5.)

There is an apparent increase in the statutory roll of $\$ 1,200$, but no actual increase, as indicated in the following table:

Transfer irom lump fund for general expenses, which fund has heen correspondingly reduced:

1 clerk, class 1

Apparent increase................................... 1,200 
GENERAL EXPENSES.

Enforcement of the insecticide act (p. 87, line 21).-There is an apparent decrease in this item of $\$ 9,790$, but, as $\$ 1,200$ has been transferred to the statutory roll, the actual decrease is $\$ 8,590$.

\section{FEDERAL HORTICULTURAL BOARD.}

\section{STATUTORY SALARIES.}

(P. 88, line 5.)

The statutory roll of the Federal Horticultural Board carries an apparent increase of $\$ 2,000$, but there is no actual increase, as indicated in the following table:

Transfer from lump fund for enforcement of plant quarantine act, which fund has been correspondingly reduced:

1 executive clerk................................. $\$ 2,000$

Apparent increase............................... $\$ 2,000$

GENERAL EXPENSES.

Enforcement of the plant-quarantine act (p. 88, line 18).- There is an apparent increase in this item of $\$ 52,750$, but, as $\$ 2,000$ has been transferred to the statutory roll, the actual increase is $\$ 54,750$.

It is proposed to develop a port inspection service for the purpose of cooperating with officials of the Customs Service and with State officials in the enforcement of quarantines established under the provisions of the plant-quarantine act. The department is now enforcing 14 quarantines prohibiting or restricting the entry of foreign plants, fruits, and plant products. It is also enforcing seven order's regulating and restricting the entry of additional foreign products. These quarantines and orders are being enforced in cooperation with the Customs Service, but the burden on that service has grown to such an extent that it has been necessary for the Department of Agriculture to take orer the actual enforcement of these quarantines at the principal ports of entry, as far as possible, through the service now maintained to prevent the entry into the United States of the pink bollworm of cotton through importations from Egypt, Mexico, and other foreign countries. California and Florida are the only States which have established adequate port inspection services. The department has been able to collaborate with and secure the aid of these State services in the enforcement of the Federal quarantines and restrictive orders now in force. The value of these State services has been fully demonstrated; their work affords a large measure of protection to the whole country. It has become apparent that the port inspection service of this department, already undertaken in a limited way, should be greatly strengthened and enlarged. Without such service new plant enemies may constantly be brought into the United States, thus practically nullifying the protection of existing quarantines.

Eradication of the potato wart (p. 89, line 1).-There is a decrease in this item of $\$ 14,700$. 
Plant quarantine in the District of Columbia (p. 89, line 14). - I new provicion has been added amending the plant quarantine act approved August 20, 1912, by adding at the end thereof the following section:

That the plant quarantine act approred Auqust 20, 1912 (3rth Stat., p. 315), be, and is hereby, amended by adding at the end thereof the following section:

Sec. 15. That in order further to control and eraticale and to prevent the dissemination of dangerous plant diveaves and insect infections and infestations no plant or plant products for or capable of propagation, including nursery stock, hereinafter referred to as pilamt: and plant products, shall be mored or allowed to be mored, shipped, transported. or cerried by amy means whaterer into or out of the Inistrict of columbia, ercept in complimen with such rules and regulations as shall be prescribed by the secretary of Agricullun as herreinafter provided. Whenever the Secretary of Agriculture, after invetigation. shall determine that any plants and plant prodicts in the l)ivtrict of columbin are infe torl or infected with insect pests and diseases and that amy place, articles, and mub tatimes weed or connected therewith are so infested or infected. written notice thereof sherl lie given by him to the owner or person in possession or control thereof, and such ouner or person shall forthwith control or eradicate and merent the dis:mination of such in-ret pest or diease and shall remoie, cut, or destrong such infe-ted and infoctert plamts. plant produets, and articles and smbstances nesd or mmected themith, which are herby declared to be nuisances, within the time and in the manner required in aid notice or by the rules and regulations of the Secretary of Agriculture. Whenever such ouner or perion can not be found, or shall fail, neglect, or refuc to comply

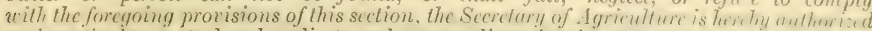
and required to control and eradicate and prevent disscmination of such insect prest of disertse and to remoce, cut, or destroy infested or infected plants and planit prorlueds amel art irles amel substences used or connected therewith, and the Lnited States shall hare an an'ium of dith against such ouner or persons for expenses ineurred by the Secretary of Atricullure in llate behalf. Employes of the Federal IIorticullural Board are hereby aulhorized and requirad

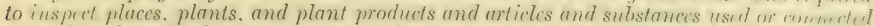
therewith whenever the Secretary of Agriculture shall determine that such ins):cetions are necessary for the purposes of this section. For the purpose of earrying out the pror isions and requirements of this section and of the rules and regulations of the Secretury of Lericulture made hereunder. and the notices given pursuant thereto. employges of the Ferleral

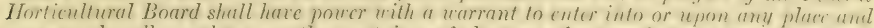
open any bundle. package, or other container of plants or plant products whe meiter lley shall

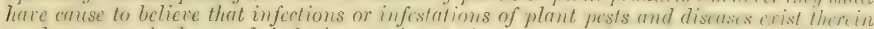
or thereon. and when such infections or infestutions are found to erist. afler notice by the Secretary of Agriculture to the owner or person in possession or control thereof and an opportunily by said ouner or person to be hermet. to destroy the infected or infested thents or plant products contained thercin. The polies court or the municijul. court of the District of Columbin shall have poure, upon information supported by oalh or affirateition stowing

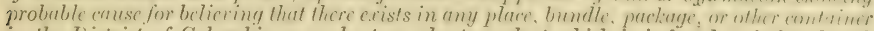
in the District of Columbia any plant or plant product which is infected or infested with

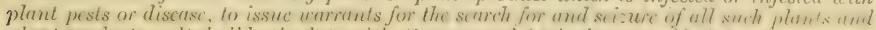

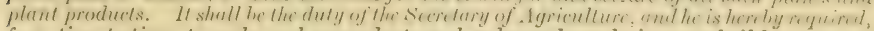
from time to time, to make and promulgate such rules and regulations as shall be neccssary to carry out the purposes of this section, and any person who shall move or allow to be morcd, or shall ship, transport, or carry, by any means whatever, any plant or plant producls from or into the District of Columbia, except in compliance with the rulcs and regulations prescribed under this section, shall be prenished, as is provided in section 10 of this act."

This amendment to the plant quarantine aret. wheh received the

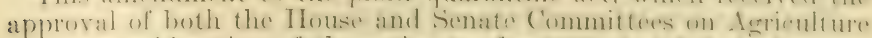

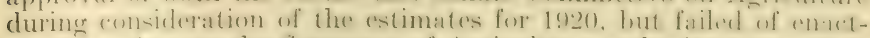
ment, confers on the sereretary of Aerieulture amtherity to resulate the moxement of plants and plant produets, including nursery stork.

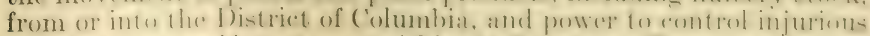
plant diseatses and inseret pests within the District. 'There is at present no law under which the movement of discased and inseret-infesterl nursery sterels and other plants and plant products inte the T)istricte of Columbia from surrounding or other States or from the District of

H. Rept. 596, 66-2-3 
Columbia into surrounding or other States can be adequately controlled; nor is there authority for control and exterminstion within the District of Columbia of plant pests and diseases. 'The powers requested are such as are exercised in practically all the States and Territories of the I'nited Strtes and are necessiry for the alignment of the Distriet of Columbin with plont pest control exereised elsewhere.

The immedinte need of this legislation is evidenced by the fact that the oriental fruit moth, which threatens seriously to affect the fruit industry of the United States, g ined entrance in large part through importations of ormamental stock into the District of Columbia, and there exist now within the District thousands of peach, cherry, plum, apple, and other trees infested with this insect, affording breeding sourees from which the moth has spread to the adjacent States of Maryland and Virginia.

MISCELLANEOUS.

DEMONSTRATIONS ON RECLAMATION PROJECTS.

(P. 92, line 18.)

There is an apparent decrease in this item of $\$ 18,600$, but, as $\$ 1,600$ has been transferred to the statutory roll of the Bureau of Plant Industry, the actual decrease is $\$ 17,000$.

\section{FIGHTING AND PREVENTING FOREST FIRES.}

$$
\text { (P. 93, line 1.) }
$$

This is a new item. It carries an appropriation of $\$ 250,000$, but includes $\$ 150,000$ now provided in the item for fighting forest fires under general expenses of the Forest Service, so that the actual increase in the fund for fighting forest fires is only $\$ 100,000$. It was the committee's thought that this appropriation would be treated as an insurance fund, to be expended only in case of actual necessity. For several years past the appropriation provided for fighting forest fires has been insufficient and annually the department has had to submit estimates for deficiency appropriations.

COOPERATIVE FIRE PROTECTION OF FORESTED WATERSHEDS OF NAVIGABLE STREAMS.

$$
\text { (P. 93, line 5.) }
$$

There is a decrease in this item of $\$ 25,000$.

EXPERIMENTS AND DEMONSTRATIONS IN LIVE-STOCK PRODUCTION IN THE CANE-SUGAR AND COTTON DISTRICTS OF THE UNITED STATES.

(P. 93, line 15.)

There is a decrease in this item of $\$ 13,500$. The words "the erection of barns and other necessary buildings" have also been omitted. 
EXPERIMENTS IN DAIRYING AND LIVE-STOCK PRODICTION IN SFMIARID ANI) IRRIGATED DISTRICTS (IF THE WESTERN UNITEI) STATES.

(P. 4, line 1.)

There is a decrease in this item of $\$ 10,000$. Authority for "the erection of barns and other necessary buildings" has been eliminated from this item.

PASSENGER-CARRYING VEHICLES.

(P. 94, line 11.)

This paragraph carries no appropriation. The amount authorized to be expended for the purchrae, maintenance, repair, and operation of passenger-carrying rehicles outside of the I istrict of Columbin has been reduced by $\$ 15,000$.

The committee has also eliminated the word " pureliase" from this item, as well as the proviso permitting the expendituse of $\$ 15,000$ from lump-fund appropriations of the department for the purchase of passenger-carrying vehicles.

\section{EXCHANGE OF PARTS OF VEHICLES.}

(P. 94, line 21.)

The following new paragraph has been inserted:

That hereafter the Sccretary of Agriculture may cxchange used parts, acesssorics, tircs, or cquipment of motor-propelled and horse-draun vehicles in part payment for new parls, accessories. tires. or equipment of such vehicles anthorized to be purchased by him, to be used for the same purposes as those proposed to be exchanged.

This legislation is recommended in order to provide authority for the exchange of parts of automobiles in part parment for similar new parts for their replacement, with a view to place the operation of automobiles by the department on an economical and businesilie basis. Tires, for example, of ten are sold upon a guaranteed niluage basis, the manufacturer agreeing, in ease they prove defective and fail to make the guaranteed mileage on aceount of imperfeetion in material or workmanship, to replace them at a figure caleulated to compensate for the lack of service rendered by them.

\section{ERADICATION OF THE FOOT-AND-MOUTII AND OTHER CONTAGIOUS DISEASES OF ANIMALS.}

\section{(P. 95, line 3.)}

The amount of this item has heen redueed from $81.0(100.1000$ to S.5(1.000. In anmual apperepriation of $81,000,000$ has been provided in the agrieveltural appropriation act for sereral years paset. This

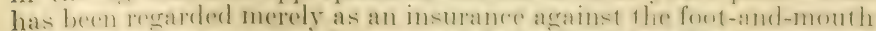
disease and a very small amount of the fund has been expented ammually. The language of the paraeraph has heen amemeled to as to eomtinue the avabiability of the mexpended balanere of the

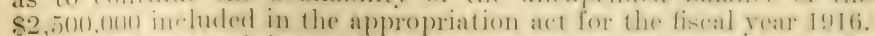
The balande remaining under that apprepriatem is appros imately \$514,000. which, it is heliered, will amply provide for possible outbreaks of the discase during the next fiscal year. 


\section{ERADICATION OF PINK BOLLWORM.}

(P. 96, line 16.)

There is an apparent decrease in this item of $\$ 307,240$, but as $\$ 9,840$ has been transferred to statutory rolls, the actual decrease is $\$ 297,400$.

MILEAGE RATES FOR MOTOR VEHICLES.

(P. 98, line 8.)

The paragraph fixing maximum mileage rates for motor vehicles has been amended so as to make its provisions applicable to the next fiscal year.

INVESTIGATIONS AND PREVENTION OF PLANT-DUST EXPLOSIONS AND FIRES.

\section{(P. 98, line 15.)}

This is a new item and prorides an appropriation of $\$ 25,000$.

Plant-dust explosions and fires in grain mills and elevators, thrashing machines, and cotton gins have resulted in the loss of scores of human lires as well as enormous property losses. The campaign conducted cooperaticely by the Bureau of Chemistry, Bureau of Markets, and Bureau of Plant Indistry under the funds prorided in the food-production act last year were of great benefit to the agricultural, grain, and milling industries of the country in reducing these losses. It also brought out many problems which previous investigations did not solve, and indicated rery clearly the importance of making provision for the continuation of the inrestigational work upon which the campaign was based. Explosions and fires in three types of plants were dealt with, namely, mills and elerators, thrashing machines, and cotton gins. As the funds provided for the work under the food-production act were withdrawn June 30, 1919, it was necessary to discontinue the demonstration work on that date and to take steps to terminate the appointment of the men engaged upon it. Because of the savings that had been effected, the Tnited States Grain ('orporation indicated its desire to carry on the work, in so far as it related to grain elevators and flour mills, and reomployed some of the men formerly engaged thereon, and it is now cooperating with this department in so far as the very limited funds of the Bureau of Chemistry will permit.

This work is conducted chiefly as an educational campaign of prerention, and it is impossible, with existing funds and facilities, to undertake in an adequate manner the essential investigational work which was suspended at the outbreak of the war. The activities of the department in connection with the prevention of plant-dust explosions and fires involve the close and effective cooperation of the Bureaz of Chemistry, Bureau of Markets, and Bureau of Plant Industry. Each of the bureaus is equipped to deal with a particular phite of the problem, and there is a thorough understanding among them regarding the matter. 


\title{
ACCUMULATIVE LEAVE OF EMPLOYEES AT INSULAR STATIONS.
}

\author{
(P. 99, line 3.)
}

The following new item has been inserted:

Hereafter. if ony employee of the Department of Agriculture assigned to permanent dutu in Alaska, Hawaii, Porto Rico, Guam, and the Virgin Islands shall elect to postpone taking any or all of the annual leave to which he may be entitled, he may, in the discretion of the Secretary of Agriculture, subject to the interests of the public service, be allowed to tale at one time in any calendar year unused annual leave which may have accumulated within not to exceed four calendar years immediately preceding and be paid at the rates prevailing during the year such leave has accumulated.

This legislation is recommended in order to make the accumulative leare rrivilege anplicable to all employees of the department assigned to rermanent duty in the insular possessions and in Alaska. The existing law applies only to the employees of the States Relations Service. 



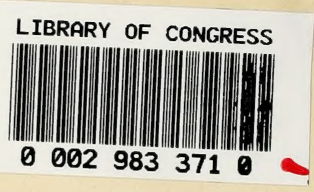

